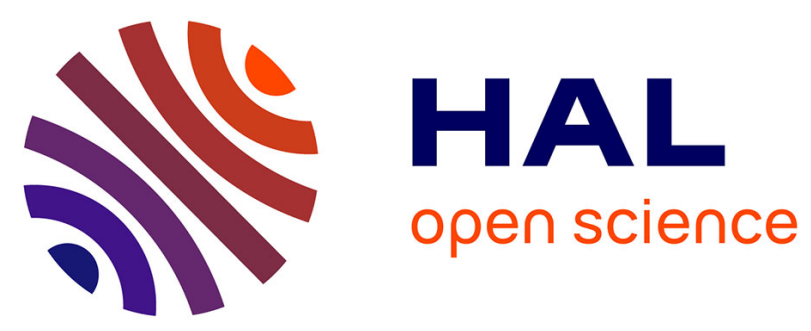

\title{
Bank Regulatory Capital and Liquidity: Evidence from U.S. and European publicly traded banks
}

\author{
Isabelle Distinguin, Caroline Roulet, Amine Tarazi
}

\section{To cite this version:}

Isabelle Distinguin, Caroline Roulet, Amine Tarazi. Bank Regulatory Capital and Liquidity: Evidence from U.S. and European publicly traded banks. Journal of Banking and Finance, 2013, 37 (9), pp.32953317. 10.1016/j.jbankfin.2013.04.027 . hal-01087426

\section{HAL Id: hal-01087426 https://hal.science/hal-01087426}

Submitted on 26 Nov 2014

HAL is a multi-disciplinary open access archive for the deposit and dissemination of scientific research documents, whether they are published or not. The documents may come from teaching and research institutions in France or abroad, or from public or private research centers.
L'archive ouverte pluridisciplinaire HAL, est destinée au dépôt et à la diffusion de documents scientifiques de niveau recherche, publiés ou non, émanant des établissements d'enseignement et de recherche français ou étrangers, des laboratoires publics ou privés. 


\title{
Bank Regulatory Capital and Liquidity:
}

\section{Evidence from U.S. and European publicly traded banks}

\author{
Isabelle Distinguin ${ }^{\mathrm{a}}$, Caroline Roulet ${ }^{\mathrm{ab}}$, Amine Tarazi $^{\mathrm{a}}$ \\ ${ }^{a}$ Université de Limoges, LAPE, 5 rue Félix Eboué, 87031 Limoges Cedex, France \\ ${ }^{\mathrm{ab}}$ OECD, 2 Rue André Pascal, 75116 Paris Cedex, France
}

This version: March 2013

\begin{abstract}
The theory of financial intermediation highlights various channels through which capital and liquidity are interrelated. Using a simultaneous equations framework, we investigate the relationship between bank regulatory capital and bank liquidity measured from on-balance sheet positions for European and U.S. publicly traded commercial banks. Previous research studying the determinants of bank capital buffer has neglected the role of liquidity. On the whole, we find that banks decrease their regulatory capital ratios when they face higher illiquidity as defined in the Basel III accords or when they create more liquidity as measured by Berger and Bouwman (2009). However, considering other measures of illiquidity that focus more closely on core deposits in the United States, our results show that small banks strengthen their solvency standards when they are exposed to higher illiquidity. Our empirical investigation supports the need to implement minimum liquidity ratios concomitant to capital ratios, as stressed by the Basel Committee; however, our findings also shed light on the need to further clarify how to define and measure illiquidity and also on how to regulate large banking institutions, which behave differently than smaller ones.
\end{abstract}

JEL classification: G21; G28

Keywords: Bank Regulatory Capital; Liquidity; Bank Regulation

\footnotetext{
'Corresponding author.

Tel: +33-555-14-92-16. E-mail addresses: isabelle.distinguin@unilim.fr (I. Distinguin), caroline.roulet@,oecd.org (C. Roulet), amine.tarazi@unilim.fr (A. Tarazi).
} 


\section{Introduction}

Liquidity transformation is traditionally considered the preeminent function of banks, but also the primary source of their vulnerability and a justification for their protection through a public safety net in the form of deposit insurance (Bryant, 1980; Diamond and Dybvig, 1983). Indeed, an important role of banks in the economy is to provide liquidity by funding long-term, illiquid assets with short-term, liquid liabilities. Thus, banks hold illiquid assets and provide cash to the rest of the economy. Therefore, they face risk if some liabilities invested in illiquid assets are claimed at short notice. The subprime crisis well illustrates how quickly and severely illiquidity can crystallize. In particular, it shows how some sources of funding can evaporate, compounding concerns about the valuation of assets and capital adequacy rules (BIS, 2009).

The existing theoretical and empirical literature considers the causal link that goes from bank capital to liquidity creation. The theoretical literature provides two opposing views on this relationship. As discussed by Berger and Bouwman (2009), under the first view, bank capital tends to impede liquidity creation through two distinct effects: the "financial fragility structure" and the "crowding-out of deposits". According to the "financial fragility structure", higher capital is associated with less monitoring which leads to less liquidity creation (Diamond and Rajan, 2000, 2001), while higher capital ratios could crowd out deposits and thereby reduce liquidity creation (Gorton and Winton, 2000). Under the second view, higher capital enhances the ability of banks to create liquidity because it allows them to absorb greater risk (Bhattacharya and Thakor, 1993; Repullo, 2004; Von Thadden 2004).

While theory suggests a causal relationship from capital to liquidity creation, in practice, the issue is more complex and both might be jointly determined ${ }^{1}$. Indeed, the more banks create liquidity, the more they are exposed to the risk of being unable to meet unexpected withdrawals from customers. Thus, banks may need to strengthen their solvency to access external funding more easily or, in extreme cases, to face unexpected losses from selling some assets at fire-sale prices (Matz and Neu, 2007).

Banks must comply with capital standards through minimum requirements for risk weighted capital ratios. However, most banks hold an amount of capital that exceeds the minimum imposed by regulation. From this perspective, various studies investigate why

\footnotetext{
${ }^{1}$ Berger and Bouwman (2009) point out this endogeneity issue. Consequently, they interpret their results as correlations between capital and liquidity creation rather than causal relationships. Their study focuses on the determinants of liquidity creation. Capital is one of their independent variables, and they address endogeneity using instrumental variable regressions.
} 
banks buildup such capital buffers (Lindquist, 2004; Jokipii and Milne, 2008; Ayuso et al., 2004). However, this literature does not consider the role of liquidity in analyzing bank regulatory capital buffer.

The purpose of this paper is to study the relationship between bank regulatory capital ratios and liquidity. We study the contribution of liquidity in explaining bank regulatory capital ratios beyond the determinants considered in the literature. Specifically, we question whether banks maintain or strengthen their regulatory capital ratios when they face higher illiquidity. In this context, we hypothesize that banks might strengthen their solvency standards to offset their liquidity constraint and improve their ability to raise external funds. In addition, banks might raise their capital standards to better assume the losses from selling illiquid assets to repay the liabilities claimed on demand. If the hypothesis is rejected-that is, if banks do not adjust and improve their capital standards when facing higher illiquidityliquidity requirements concomitant to capital standards might be needed to temper the overall riskiness of banks. From this perspective, we also contribute to the debate on liquidity regulation implemented in the Basel III regulatory framework ${ }^{2}$.

We extend the current literature in several directions. First, we add to the strand of the existing empirical literature on bank capital buffer, in that liquidity has not yet been considered a determinant of capital buffer. Second, to be consistent with recent empirical findings showing that bank capital and liquidity might be jointly determined, we estimate a simultaneous equations model. Third, we consider both a liquidity creation indicator in the steps of Berger and Bouwman (2009) and a liquidity indicator in line with the definition of the Basel Committee on Banking Regulation and Supervision (i.e., the net stable funding ratio). The net stable funding ratio shows to what extent a bank is able to meet its liquidity requirements without borrowing money or selling its assets at a loss. This measure accounts for the imbalances of both sides of bank balance sheets and enables regulators to better assess the ability of banks to meet unexpected customer withdrawals from their liquid assets. The main difference between the liquidity creation indicator and the liquidity indicator as defined in the Basel III accords stems from the liability side of the balance sheets. The liquidity creation indicator considers some liabilities as liquid because they can be quickly withdrawn

\footnotetext{
${ }^{2}$ Two regulatory standards for liquidity have been introduced (BIS, 2009). The "net stable funding ratio" identifies the amount of long-term, stable sources of funding an institution uses relative to the liquidity profiles of its assets and the potential for contingent calls on funding liquidity arising from off-balance-sheet commitments and obligations. The standard requires a minimum amount of funding that is expected to be stable over a one year-time horizon based on liquidity factors assigned to assets and off-balance-sheet commitments. The Basel Committee has also introduced the "liquidity coverage ratio" to promote the short-term resiliency of the liquidity profile of institutions by ensuring that they have sufficient high-quality liquid resources to survive an acute stress scenario lasting for one month.
} 
without penalty. However, a large share of these liquid liabilities is considered as stable in the Basel III liquidity indicator because they are expected to "stay" within the institution. From these two approaches to measure bank liquidity, we investigate how bank managers deal with the stability of their funding in the definition of bank liquidity. We measure the liquidity created by banks or their exposure to liquidity risk only from on-balance sheet positions because a detailed breakdown of off-balance sheets is not available in standard databases for European banks. This could alter our results for large banks because they are generally more involved in off-balance sheet activities, and specifically in sophisticated instruments, than small banks ${ }^{3}$. Finally, we also add to the literature by assessing the accuracy of improving the regulatory framework by adding liquidity requirements to capital standards.

Our investigation requires market data and a detailed breakdown of bank balance sheets to compute liquidity indicators. This information is more frequently and extensively reported for listed banks in standard databases. Our sample is therefore limited to publicly traded U.S. and European commercial banks ${ }^{4}$ during the pre-crisis 2000-2006. We omit the crisis years 2007 and 2008 that are likely to disturb our analysis. The main results show that banks decrease their regulatory capital ratios when they face higher illiquidity as defined in the Basel III accords or when they create more liquidity as measured by Berger and Bouwman (2009). However, considering a different definition of stable liabilities specific to U.S. banks based on the concept of core deposits, the results show that small banks actually increase their regulatory capital ratios when they are exposed to higher illiquidity. The findings support the need to implement minimum liquidity ratios concomitant to capital ratios, as stressed by the Basel Committee. Nevertheless, the results also shed light on the need to further clarify how to define and measure illiquidity.

The remainder of this paper is organized as follows. Section 2 reviews existing literature on bank liquidity creation and on the determinants of bank capital buffer. Section 3

\footnotetext{
${ }^{3}$ In their empirical study on the determinants of liquidity creation, Berger and Bouwman (2009) indicate that their results differ for large banks but not for small banks when they account for off-balance sheet positions. More precisely, for large banks, capital and liquidity creation are positively correlated when they use measures that include off-balance sheet activities, while the relationship is insignificant when those activities are excluded. For small banks, capital and liquidity creation are negatively correlated using measures with or without offbalance sheet activities.

${ }^{4}$ Some of these banks perform non-commercial banking activities (e.g., JP Morgan Chase owns one of the largest hedge funds in the United States). We carry out robustness checks by running estimations on a subsample limited to "true commercial banks". We exclude a bank if it is very small (total assets below \$25 million) or if it has consumer loans exceeding $50 \%$ of total assets. Besides, we verify that our sample does not include a bank with no loans outstanding, zero deposits or zero or negative equity capital. For further details, see section 6. In all cases, the main conclusions are consistent with those obtained with our full sample of banks.
} 
presents the dataset and the empirical strategy, while section 4 describes the variables considered in the analysis. Results and robustness checks are presented in sections 5 and 6 . Section 7 presents concluding remarks.

\section{Related literature}

Our research is related to two strands of literature: the theories linking bank capital and liquidity creation and studies focusing on the determinants of bank capital buffer. Several theory papers deal with the relationship between bank capital and liquidity creation. In their work, Berger and Bouwman (2009) note that two hypotheses largely frame the discussion on this relationship: the "financial fragility/crowding-out" hypothesis and the "risk absorption" hypothesis.

Roughly described ${ }^{5}$, the "financial fragility structure" effect is the outcome of the following process. The bank collects funds from depositors and lends them to borrowers. By monitoring borrowers, the bank obtains private information that gives it an advantage in assessing the profitability of its borrowers. However, this informational advantage creates an agency problem, and the bank might extort rents from its depositors by requiring a greater share of the loan income. If depositors refuse to pay the higher cost, the bank withholds monitoring or loan-collecting efforts. Because depositors know that the bank might abuse their trust, they become reluctant to put their money in the bank. Consequently, the bank must win depositors' confidence by adopting a fragile financial structure with a large share of liquid deposits. A contract with depositors mitigates the bank's hold-up problem because depositors can run on the bank if the bank threatens to withhold efforts. Consequently, financial fragility favors liquidity creation in that it allows the bank to collect more deposits and grant more loans. In contrast, higher capital tends to mitigate the financial fragility and enhances the bargaining power of the bank, which hampers the credibility of its commitment to depositors. Thus, higher capital tends to decrease liquidity creation. In addition, Gorton and Winton (2000) show that a higher capital ratio can reduce liquidity creation through another effect: the "crowding-out of deposits". They maintain that deposits are more effective liquidity hedges for agents than investments in bank equity. Indeed, deposits are totally or partially insured and withdrawable at par value. In contrast, bank capital is not exigible and has a stochastic value that depends on the state of bank fundamentals and the liquidity of the

\footnotetext{
${ }^{5}$ See Berger and Bouwman (2009) for a longer discussion on the "financial fragility structure" and the "crowding-out of deposits" effects.
} 
stock exchange. Consequently, higher capital ratios shift investors' funds from relatively liquid deposits to relatively illiquid bank capital. Thus, the higher is the bank's capital ratio, the lower is its liquidity creation.

Under the second hypothesis, higher capital enhances the ability of banks to create liquidity. Here, liquidity creation increases the bank's exposure to risk, as its losses increase with the level of illiquid assets to satisfy the liquidity demands of customers (Allen and Gale, 2004). Bank capital allows the bank to absorb greater risk (Bhattacharya and Thakor, 1993; Repullo, 2004; Von Thadden 2004). Thus, the higher is the bank's capital ratio, the higher is its liquidity creation.

Berger and Bouwman (2009) empirically test these recent theories of the relationship between capital and liquidity creation. Using a sample of U.S. commercial banks from 1993 to 2003, they find that the relationship is positive for large banks when liquidity creation includes off-balance sheet activities and not significant when liquidity creation only accounts for on-balance sheet activities. The relationship is significantly negative for small banks considering both liquidity creation measures.

Besides, the liquidity creation indicator developed by Berger and Bouwman (2009) has been used in several other studies to investigate different issues. Fungacova et al. (2010) examine how the introduction of deposit insurance influences the relationship between bank capital and liquidity creation. They test the two competing hypotheses highlighted by Berger and Bouwman (2009) using a sample of Russian banks from 1999 to 2007 . They find that the implementation of deposit insurance has a limited impact on the relationship between bank capital and liquidity creation and does not change the negative sign of the relationship. Angora and Roulet (2011) use the Berger and Bouwman (2009) liquidity creation and the Basel III net stable funding (BIS, 2009) measures on a sample of U.S. and European publicly traded commercial banks during the 2000-2008 period. They show that European banks and large U.S. banks create higher levels of liquidity and are more exposed to maturity transformation risk than small U.S. banks. Typically, the results show that banks' size explains the differences in liquidity creation and in maturity transformation risk. Horvath et al. (2012) investigate the relationship between capital and liquidity creation by performing Granger-causality tests for a sample of Czech banks from 2000 to 2010. They show that capital and liquidity creation negatively Granger-cause each other and highlight a trade-off between higher financial stability provided by stronger capital requirements and the benefits stemming from higher liquidity creation. Besides, Imbierowicz and Rauch (2012) investigate the relationship between the two major sources of bank default risk: liquidity risk and credit 
risk. They use a sample of virtually all U.S. commercial banks during the 1998-2010 period. They consider the liquidity creation indicator of Berger and Bouwman (2009) as a proxy of liquidity risk. Overall, they find that both liquidity and credit risks contribute to bank default. They also show that the simultaneous occurrence of both risk factors increases bank default risk. Finally, Berger et al. (2012) study the effects of regulatory interventions and capital support on bank risk taking and liquidity creation using a unique dataset over the 1999-2009 period They find that both types of actions are generally associated with statisticallysignificant reductions in risk taking and liquidity creation in the short and long run.

Turning to the empirical literature on the determinants of bank capital buffer, the studies mainly focus on the relationship between a given determinant and bank capital buffer by controlling for other potential determinants. From this perspective, Lindquist (2004) uses Norwegian banks to study the impact of the riskiness of bank assets on capital buffer. Regulatory capital requirements are only based on credit, market and operational risks and do not cover all types of risk. Furthermore, sophisticated risk valuation models might underestimate risk. Therefore, banks might hold capital in excess of the minimum required by regulators so they can face unexpected losses from their risky assets. However, Lindquist (2004) does not find any significant link. Jokipii and Milne (2011) also focus on the relationship between risk and bank capital buffer, but they examine the relationship between capital buffer and portfolio risk adjustments. Using U.S. bank holding companies and commercial banks over the 1986-2006 period, they find a positive two-way relationship. Several studies investigate how the business cycle might influence bank capital buffer, as much debate on Basel capital standards has centered on its potential "pro-cyclicality". Ayuso et al. (2004) and Stolz and Wedow (2011) consider Spanish and German banks, respectively. Bikker and Metzemakers (2004) and Jokipii and Milne (2008) focus on banks from 29 OECD countries and from 25 European countries, respectively. Their results globally highlight a significant negative co-movement with the cycle. Banks tend to decrease (increase) their capital buffer during upturns (downturns). Other studies consider the impact of market discipline in the determination of bank capital buffer. They empirically test whether market discipline provides enough incentives for banks to strengthen their capital buffer to mitigate their default risk. For example, Flannery and Rangan (2008) study the causes of the bank capital buildup of the 1990s for large U.S. banks. They find that among the relevant factors, market discipline explains the bulk of this buildup. Alfon et al. (2004) and Nier and Baumann (2006), using a sample of UK banks and a large cross-country panel data set from 32 
countries, respectively, show that moral hazard is effective and that market discipline encourages banks to strengthen their capital buffer. Fonseca and Gonzalez (2010) consider cross country data from 70 countries and investigate whether the influence of market discipline on capital buffer varies across countries with heterogeneous frameworks for regulation, supervision and institutions. They find that, even if market discipline has a positive impact on bank capital buffer, the relationship depends on several structural factors. Indeed, restrictions on bank activities, effective supervision and bad institutional environment tend to weaken market discipline and reduce incentives for banks to hold capital in excess of the minimum required by regulators.

\section{Sample and empirical method}

\subsection{Presentation of the sample}

Our sample includes U.S. and European ${ }^{6}$ publicly traded commercial banks over the 2000-2006 period. We deliberately omit the crisis years 2007 and 2008 that are likely to disturb our analysis. We consider U.S. and European banks because the required data are available on standard databases to ensure an accurate representativeness of the sample of banks in each country. Furthermore, we include only listed banks because the setting requires market data (i.e., market value of assets, dividends) and a detailed breakdown of bank balance sheets to compute liquidity indicators. In standard databases, this information is more frequently and extensively reported for listed banks.

Annual consolidated financial statements were extracted from Bloomberg. We also consider data from the World Bank's 2007 Regulation and Supervisory Database (Barth et al., 2007) to compute an indicator of regulatory oversight of bank capital.

From 2000 to 2006, we identify 870 listed commercial banks (645 in the United States and 225 in Europe). To enable the liquidity indicator computation, we restrict the sample to banks for which the breakdown for loans by category and the breakdown for deposits by maturity were available in Bloomberg or in annual reports. We also delete a bank if its total

\footnotetext{
${ }^{6}$ The sample includes banks from the 27 EU member countries, Norway and Switzerland. However, the required data are available only for banks located in the 20 following countries: Austria, Belgium, Cyprus, Denmark, Finland, France, Germany, Greece, Iceland, Ireland, Italy, Liechtenstein, Malta, the Netherlands, Norway, Portugal, Spain, Sweden, Switzerland and the United Kingdom.
} 
regulatory capital ratio is lower than the regulatory minimum requirement ${ }^{7}$. Such a bank is likely to behave very differently from banks that are in compliance because it is under close regulatory scrutiny and it might face constraints on its activities. Our final sample consists of 781 commercial banks (574 in the United States and 207 in Europe). Table 1 presents the distribution of banks by country and the representativeness of the sample. We compare aggregate total assets of banks included in the final sample with aggregate total assets of the whole banking system. Over the 2000-2006 period, the final sample accounts, on average, for $66.4 \%$ of the total assets of U.S. commercial banks as reported by the Federal Deposit Insurance Corporation (FDIC) and $60.4 \%$ of the total assets of European commercial banks as reported by central banks.

\section{[Insert Table 1]}

Table 2 presents some general descriptive statistics of the final sample including U.S. and European banks. By using several key accounting ratios, the data highlight that banks are on average focused on traditional intermediation activities. However, there is a high heterogeneity across banks according to their size. The data show that small banks ${ }^{8}$ both in Europe and in the United States are on average more focused on traditional intermediation activities than large banks. The average share of loans in total assets is $65.4 \%$ on the whole sample of banks, and respectively $63.5 \%$ for large U.S. banks, $63.2 \%$ for large European banks, $67.6 \%$ for small U.S. banks and $67.9 \%$ for small European banks. The average ratio of total deposits to total assets is $70.7 \%$ on the whole sample but it conceals large differences between banks. For large banks, the average ratio of total deposits to total assets is $73.9 \%$ in the U.S. and $47.6 \%$ in Europe. The average ratio of total deposits to total assets of small U.S. banks is $90.7 \%$ and $69.1 \%$ for small European banks. In addition, average interest income accounts for nearly three-quarters of total income (72\%). However, there is a high heterogeneity across banks, as shown by the high standard deviation and extreme values of

\footnotetext{
${ }^{7}$ We take in account that regulators set the minimum requirement at $8 \%$ for the ratio of Tier 1 and 2 capital to total risk weighted assets, except in Cyprus where it is equal to $10 \%$ and in the United Kingdom where it can be considered equal to $9 \%$ following Jokipii and Milne (2008). Regarding the ratio of Tier 1 capital to total risk weighted assets, the minimum requirement is at $4 \%$ in all countries.

${ }^{8}$ Following the literature, a bank is considered small if its total assets are below US\$1 billion. Considering U.S banks, the sample includes 357 banks with total assets below US\$1 billion of a total of 574 U.S. banks. This accounts for $62.2 \%$ of the total number of U.S. banks in our sample. Considering European banks, the sample includes only 37 banks with total assets below US\$1 billion of a total of 207 European banks. These banks represent only $17.8 \%$ of the total number of European banks in our sample.
} 
each ratio. Considering the ratios of total loans to total assets and total deposits to total assets, minimum values are respectively equal to $4.8 \%$ and $4.1 \%$. We check that these very low minima are not outliers but prevail for several large European banks. We therefore keep these observations in the panel. Regarding the quality of bank assets, the average share of loan loss provisions in total loans is $0.4 \%$. Considering profitability, the average return on assets is equal to $0.9 \%$. Last, in terms of capitalization, the average risk weighted capital ratio is at $13.4 \%$, and the average ratio of Tier 1 capital to total assets is $8.4 \%$.

\section{[Insert Table 2]}

\subsection{The model and regression framework}

In this paper, we investigate the contribution of liquidity in explaining bank regulatory capital buffer beyond the determinants considered in the existing literature. Regulatory capital buffer is defined as the amount of capital a bank holds in excess of the minimum required to meet regulatory standards. In most of the countries of the sample, regulators set the minimum requirement at $8 \%$. Thus, total regulatory capital buffer is the difference between the total regulatory capital ratio (i.e., the ratio of Tier 1 and Tier 2 capital to risk weighted assets) and a constant (8\%). To simplify, we use the total regulatory capital ratio instead of total regulatory capital buffer ${ }^{9}$. Previous studies show that bank capital might also be a determinant of bank liquidity creation (Berger and Bouwman, 2009). Thus to deal with endogeneity, we consider a simultaneous equations model. In the first equation (i.e., the regulatory capital equation), we regress the regulatory capital ratio on a set of factors identified in the previous literature, to which we add liquidity variables using several proxies. In the second equation (i.e., the liquidity equation), we regress the liquidity variable on a set of independent variables identified in previous literature. The empirical model is specified by the following simultaneous equations system (noted as system (1); subscripts $i$ and $t$ denoting bank and period, respectively):

\footnotetext{
${ }^{9}$ In section 6, we perform robustness checks considering bank regulatory capital buffers instead of bank regulatory capital ratios. We take in account that regulators set the minimum requirement at $8 \%$, except in Cyprus where it is equal to $10 \%$ and in the United Kingdom where it is equal to $9 \%$ following Jokipii and Milne (2008). Our results are consistent with those obtained considering the bank regulatory capital ratio.
} 


$$
\left\{\begin{array}{l}
\mathrm{K}_{-} \mathrm{RWA}_{\mathrm{it}}=\alpha_{\mathrm{it}}+\beta \mathrm{L}_{\mathrm{i}, \mathrm{t}}+\sum_{\mathrm{k}=1}^{\mathrm{K}} \gamma_{\mathrm{k}} \mathrm{DK}_{\mathrm{ki}, \mathrm{t}-1}+\sum_{\mathrm{j}=1}^{\mathrm{J}} \gamma_{\mathrm{j}}^{\prime} \mathrm{DK}_{\mathrm{ji}, \mathrm{t}}+\varepsilon_{\mathrm{it}} \\
\mathrm{L}_{\mathrm{i}, \mathrm{t}}=\delta_{\mathrm{it}}+\varphi \mathrm{K}_{-} \mathrm{RWA}_{\mathrm{it}}+\sum_{\mathrm{m}=1}^{\mathrm{M}} \lambda_{\mathrm{m}} \mathrm{DL}_{\mathrm{mi}, \mathrm{t}-1}+\sum_{\mathrm{n}=1}^{\mathrm{N}} \lambda_{\mathrm{n}}^{\prime} \mathrm{DL}_{\mathrm{ni}, \mathrm{t}}+\xi_{\mathrm{it}}
\end{array}\right.
$$

Previous empirical studies on capital buffer and liquidity respectively highlight potential endogeneity issues with some explanatory variables and specifically with most of the bank level indicators. To address such issues ${ }^{10}$ and following Lindquist (2004), in both the regulatory capital and the liquidity equations, we replace all bank-level explanatory variables which are presumably endogenous in the existing literature by their one-year lagged value ${ }^{11}$. $K \_R W A$ and $L$ correspond respectively to the regulatory capital ratio and to the liquidity proxy. $D K_{j}$ and $D L_{n}$ are respectively the $j^{\text {th }}$ and the $n^{\text {th }}$ exogenous determinants of the regulatory capital ratio and liquidity. $D K_{k}$ and $D L_{m}$ are respectively the $k^{\text {th }}$ and the $m^{\text {th }}$ presumably endogenous determinants of the regulatory capital ratio and liquidity.

We estimate system (1) considering the generalized method of moments (GMM). Considering this estimation method has two advantages. It is robust to the distribution of errors and it is considered more efficient than two-stage least squares (2SLS) regression because it accounts for the heteroskedasticity of errors (Hall, 2005). After testing for crosssection and time fixed versus random effects, we include cross-section and time fixed effects in the regressions.

\section{Definition of variables}

\subsection{Regulatory capital ratios}

The total regulatory capital ratio is defined as the ratio of Tier 1 and Tier 2 capital to risk weighted assets $\left(T 12 \_R W A\right)$. For deeper insights, we consider an alternative measure of the regulatory capital ratio. This is the ratio of Tier 1 capital to risk weighted assets $\left(T 1 \_R W A\right)$. Tier 1 capital consists of better quality capital and banks might be managing the different components of regulatory capital differently.

\footnotetext{
${ }^{10}$ Hausman tests are run for endogeneity by considering each equation of the system individually. The tests confirm the presence of endogeneity both in the regulatory capital and the liquidity equations.

${ }^{11} \mathrm{We}$ check that the one year lagged values of the presumably endogenous variables are not weak instruments. However, more lags of these variables are not introduced in the regressions as they are weak instruments.
} 
Since bank capital and liquidity creation might be jointly determined, the regulatory capital ratio $\left(K_{-} R W A\right)$ is the dependent variable in the regulatory capital equation of system (1) and an explanatory variable in the liquidity equation of this system ${ }^{12}$. As discussed above, the theoretical literature provides two opposite views of the impact of capital on liquidity creation. The "financial fragility hypothesis" (Diamond and Rajan, 2000 and 2001) and the "deposit crowding-out hypothesis" (Gorton and Winton, 2000) predict that higher capital will decrease bank liquidity creation. However, the "risk absorption hypothesis" postulates that higher capital will increase bank liquidity creation. Thus, the expected sign for the coefficient of this variable is ambiguous in the liquidity equation.

\subsection{Measures of liquidity}

In the banking literature, most empirical studies that consider liquidity indicators use ratios computed from accounting data (i.e., consistent with liquidity indicators of the CAMELS rating approach). However, as argued by Poorman and Blake (2005), using such liquidity ratios could be inaccurate under certain conditions. For example, a large regional bank such as the Southeast Bank of Miami, with a ratio of liquid assets to total assets above $30 \%$, bankrupted in September 1991 because of its inability to repay some liabilities claimed on demand with its liquid assets ${ }^{13}$. In addition, given the development of bank market activities, the cash value of assets that could be monetized and the availability of market funding are essential to assess bank liquidity. To deal with such issues, some empirical studies use synthetic liquidity indicators that include, in addition to the information provided by accounting data on the liquidity profile of banks, information about the cash value of assets that could be monetized and about the availability of market funding to determine the liquidity of bank assets and liabilities (Deep and Schaefer, 2004; Berger and Bouwman, 2009; BIS, 2009). Using this literature emphasizing the use of such synthetic indicators and considering the Basel III international framework for liquidity assessment in banking, we use

\footnotetext{
${ }^{12} K_{-} R W A$ is either the Tier 1 and Tier 2 capital to risk weighted assets $\left(T 12_{-} R W A\right)$ or the ratio of Tier 1 capital to risk weighted assets $(T 1 R W A)$.

${ }^{13}$ The Southeast Bank of Miami had experienced significant problems as a result of concentrated lending in commercial real estate and weak underwriting and credit administration practices. As of August 31, 1991, real estate loans at Southeast Bank of Miami totaled US $\$ 3.5$ billion, or $45 \%$ of the bank's total loan portfolio, and nonperforming assets equaled $10 \%$ of loans. Southeast Bank of Miami reported a loss of US\$116.6 million for the first quarter and US\$139 million for the second quarter of 1991. The announcement of these huge losses caused more depositors to withdraw their funds, and the bank's liquidity problems grew worse. Finally, the bank was closed on September 19, 1991, when it was unable to repay a loan from the Federal Reserve Bank of Atlanta.
} 
the following two proxies: a liquidity creation indicator $(L C)$ and the inverse ${ }^{14}$ of the Basel III net stable funding ratio $\left(I_{-} N S F R\right)^{15}$. We measure the liquidity created by banks or their exposure to liquidity risk only from on-balance sheet positions because a detailed breakdown of off-balance sheets is not available in standard databases for European banks. However, bank liquidity might be affected by on- and off-balance sheets positions. Indeed, banks can also create liquidity off the balance sheet through loan commitments to customers and similar claims to liquid funds. In addition, the potential contingent calls on funding liquidity arising from off-balance sheet commitments and obligations can generate lack of liquidity and thus increase bank illiquidity. In Berger and Bouwman (2009), liquidity creation is computed with a method similar to ours by using on-balance sheet information only but also by adding offbalance sheet items. Berger and Bouwman (2009) document that large and small banks create liquidity in very different ways considering alternately a narrow liquidity creation indicator limited to on-balance sheet positions and a broader indicator that also includes off-balance sheet positions. They show that for U.S. banks, as of 2003, unused loan commitments amount to $48 \%$ of the total liquidity created by large banks while they only account for $19 \%$ of the liquidity created by small banks. Regarding the impact of bank capital on liquidity creation, their results differ when they account for off-balance sheet positions for large banks. Indeed, the authors find a positive and significant relationship between capital and liquidity creation for large banks only when they consider their broader liquidity creation measure that includes off-balance sheet activities. For small banks, the relationship between capital and liquidity creation is significant and negative with both definitions of the liquidity creation indicator.

Our first liquidity measure is the narrow liquidity creation indicator $(L C)$ defined by Berger and Bouwman (2009) which only considers on-balance sheet positions. To compute this indicator, first, all assets and liabilities are classified as liquid, semiliquid or illiquid according to their maturity and their category. The authors assume that some assets are easier to sell than others (e.g., securitizable loans, trading assets). In addition, they assume that some liabilities can be more quickly withdrawn without penalty. Second, each asset and liability item is weighted accordingly. Table 3 shows the weights applied to bank balance sheets based on Berger and Bouwman (2009).

\footnotetext{
${ }^{14}$ We use the inverse of the Basel III net stable funding ratio. A higher value indicates higher illiquidity.

15 The Basel Committee on Banking Regulation and Supervision also introduced the "liquidity coverage ratio". This ratio is intended to promote the short-term resiliency of the liquidity profile of banks by ensuring that they have sufficient high-quality liquid resources to survive an acute stress scenario lasting for one month. This paper focuses on a one-year horizon and we do not compute such a ratio which requires the use of monthly data.
} 
Liquidity creation $(L C)$ is then calculated as follows:

$$
\mathrm{LC}=\frac{\begin{array}{c}
0.5 * \text { illiquid assets }+0 * \text { semiliquid assets }-0.5 * \text { liquid assets } \\
+0.5 * \text { liquid liabilities }+0 * \text { semiliquid liabilities }-0.5 * \text { illiquid liabilities }
\end{array}}{\text { Total assets }}
$$

All else being equal, a bank creates one dollar of liquidity by investing one dollar of liquid liabilities (e.g., transaction deposits) into one dollar of illiquid assets (e.g., business loans). Similarly, a bank destroys one dollar of liquidity by investing one dollar of illiquid liabilities or equity into one dollar of liquid assets (e.g., short-term government securities). Higher values of liquidity creation indicate higher bank illiquidity, as the bank invests more liquid liabilities into illiquid assets. In such a case, the bank is more exposed to maturity transformation risk if customers claim their funds on demand while illiquid assets are saleable at fire sale prices.

Our second liquidity proxy is based on the regulatory standards proposed by the Basel Committee on Banking Regulation and Supervision (BIS, 2009). Following the subprime crisis, in recognition of the need for banks to improve their liquidity management, the Basel Committee on Banking Regulation and Supervision developed an international framework for liquidity assessment in banking (BIS, 2009). Among the several guidelines, the Basel III accords include the implementation of the "net stable funding ratio". This ratio is intended to promote resiliency over long-term time horizons by creating additional incentives for banks to fund their activities with more stable sources of funding on an ongoing structural basis. This liquidity measure is the ratio of the available amount of stable funding to the required amount of stable funding. The available amount of stable funding is the total amount of an institution's (1) capital, (2) liabilities with effective maturities of one year or greater, and (3) portion of "stable" demand deposits (i.e., funds with maturities of less than one year that would be expected to "stay" within the institution) and of term deposits with maturities of less than one year that would be expected to "stay" within the institution. The required amount of stable funding is the amount of a particular asset that could not be monetized through sale or used as collateral in a secured borrowing on an extended basis during a liquidity event lasting one year. To calculate the "net stable funding ratio", a specific required stable funding factor 
is assigned to each particular type of asset and a specific available stable funding factor is assigned to each particular type of liability. In Table 4, we briefly summarize the composition of asset and liability categories and related stable funding factors. The higher the required amount of stable funding compared with the available amount of stable funding, the more illiquid a bank is considered. Because the regulation on bank liquidity is not yet implemented, this ratio is only an indicator of bank illiquidity as defined in the Basel III accords and does not establish a minimum acceptable amount of stable funding based on the liquidity characteristics of an institution's assets and activities over a one-year time horizon.

\section{[Insert Table 4]}

For consistency with our first liquidity measure, we consider for this second liquidity measure the inverse of the regulatory ratio (BIS, 2009). Higher values of both measures will indicate higher illiquidity. The inverse of the net stable funding ratio $\left(I \_N S F R\right)$ is the ratio of the required amount of stable funding to the available amount of stable funding. In Table A.1 (Appendix A), we show the breakdown of bank balance sheets as provided by Bloomberg and its weighting with respect to the Basel III framework to calculate the inverse of the net stable funding ratio. On the asset side, we define the type and maturity of assets consistent with the definition of BIS (2009) to apply the corresponding weights. On the liability side, we consider only the maturity of liabilities to apply the corresponding weights. Because the data only provide the breakdown of deposits according to their maturity and not according to the type of depositors, we consider the intermediate weight of $0.7^{16}$ for stable demand deposits and saving deposits (including all deposits with a maturity of less than one year). We calculate the inverse of the net stable funding ratio (I_NSFR) as follows:

\footnotetext{
$0 *$ (cash + interbank assets + short-term marketable assets $)$

$+0.5 *$ (long-term marketable assets + customer acceptances)

$+0.85 *$ consumer loans

I_NSFR $=\frac{\text { Required amount of stable funding }}{\text { Available amount of stable funding }}=\frac{+1 *(\text { commercial loans }+ \text { other loans }+ \text { other assets }+ \text { fixed assets })}{0.7 *(\text { demand deposits }+ \text { saving deposits })}$

$+0 *$ (short-term market debt + other short-term liabilities)

$+1 *$ (long-term liabilities + equity)
}

\footnotetext{
${ }^{16}$ The Basel Committee considers three different weights (i.e., 0.5 or 0.7 or 0.85 ) for demand and saving deposits (i.e., all deposits with a maturity of less than 1 year) according to the type of depositors. Here, it is the intermediate weight of 0.7 that is used. In section 6 , we perform robustness checks by considering other weights.
} 
As mentioned above, higher values of the two liquidity indicators indicate higher bank illiquidity. Higher levels of liquidity creation $(L C)$ mean that banks invest more liquid liabilities in illiquid assets. In addition, a higher inverse net stable funding ratio (I_NSFR) implies that the amount of assets that cannot be monetized is deviating from the available amount of stable funding. In this context, a bank faces risk if some liquid liabilities (i.e., unstable funding) invested in illiquid assets (i.e., assets that could not be monetized or that can be sold at loss) are claimed on demand. In our approach, we hypothesize that the rational behavior of banks is to hold more capital to assume the losses incurred by higher illiquidity. Consequently, we expect a positive sign for the coefficients of the variables $L C$ and $I$ NSFR in the determination of regulatory capital ratios.

\subsection{Variables affecting regulatory capital buffer and liquidity from previous literature}

Following the existing literature, we consider a large set of bank-level indicators and macroeconomic variables that are likely to affect bank regulatory capital ratios and liquidity respectively.

\subsubsection{Regulatory capital equation}

We include profitability in the regulatory capital equation. Because raising additional capital is costly, capital accumulation can more easily rely on funds generated internally (through higher retained earnings, weaker dividend payments and stock repurchase) in line with the "pecking order theory of finance" (Flannery and Rangan, 2008). Thus, we expect a positive relationship between bank profitability and regulatory capital ratios. We consider the return on equity as a proxy of bank profitability $(R O E)$.

Because capital accumulation will also depend on dividend policy and following Gropp and Heider (2010), we use the dividend payout ratio in the framework. We conjecture a negative relationship between the dividend payout ratio and regulatory capital ratios. The dividend payout ratio, as defined in the Bloomberg database, is the ratio of total common dividends to the difference between net income and minority interests plus preferred dividends $\left(D I V \_P Y R T\right)$.

We include the riskiness of bank assets in the regulatory capital equation. We consider the ratio of loan loss provisions to total loans (LLP_TLO) as a proxy of asset risk. Note that the expected sign for the relationship between this variable and regulatory capital ratios is not 
clear-cut. Because bank capital can be viewed as a security buffer to assume losses from risky and poor quality assets, banks willing to take higher risk might hold more capital (Berger et al., 2008; Flannery and Rangan, 2008; Nier and Baumann, 2006). However, an increase in this ex post measure of risk could lower the regulatory capital ratio, given that capital is accumulated to face unexpected losses (Ayuso et al., 2004; Fonseca and Gonzalez, 2010). On the whole, the expected sign for the coefficient of this variable is ambiguous.

Nier and Baumann (2006) indicate that the funding structure of the bank is likely to affect capital buffer. Because uninsured debtholders are likely to face large losses in case of bank failure, they are particularly sensitive to the riskiness of the bank and to its default probability. From this perspective, uninsured debtholders will feel unsafe when the bank is operating with a capital ratio close to the regulatory minimum requirement and will increase their monitoring effort. Following the literature, subordinated debtholders are expected to have the strongest incentives to monitor and discipline banks. To avoid higher funding cost, banks that are more reliant on subordinated debt will hold higher levels of capital. Therefore, we use the ratio of subordinated debts to total debts (MKT_DISC) to capture such a behavior. We expect a positive sign for the coefficient of this variable in the determination of regulatory

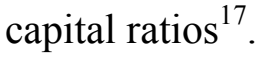

Because a bank with a higher charter value can more easily raise capital on the market, it will presumably need to hold less capital. Alternatively, as argued by Gropp and Heider (2010), bank reputation and charter value should also be protected with a large amount of capital. We use the ratio of the market value to the book value of assets $\left(M K T_{-} B K_{-} V A L\right)$ as a proxy of bank charter value. Thus, the expected sign for the coefficient of this variable in the regulatory capital equation is ambiguous.

We also include bank size in the regulatory capital equation. Large banks benefit from economies of scale in screening and monitoring borrowers and from greater diversification. In addition, because of their "too-big-to-fail" position, large banks might hold less capital in excess of regulatory requirements. Hence, a negative relationship is expected between bank size and regulatory capital ratios. We use the natural logarithm of total assets $(L N+T A)$ as a proxy of bank size. We expect a negative sign for the coefficient of this variable in the determination of regulatory capital ratios.

\footnotetext{
${ }^{17}$ This variable is only included in the equation with the ratio of Tier 1 capital to risk weighted assets as the dependent variable. It is not included when the dependent variable is defined as the ratio of Tier 1 and Tier 2 capital to risk weighted assets because a portion of subordinated debt is eligible for Tier 2 capital. For robustness, we also introduce it when the dependent variable includes both Tier 1 and Tier 2 capital. Our findings are unaltered. Results are shown in Table C.1 in Appendix.
} 
We further consider an indicator of regulatory oversight of bank capital ( $\left.C A P \_R E G\right)$ in the regulatory capital equation (Laeven and Levine, 2008; Shehzad et al., 2010). Because banking regulation is likely to vary across countries, this variable controls for possible country effects. This index is computed from the World Bank's 2007 Regulation and Supervisory Database (Barth et al., 2007). Higher values of the bank capital regulation index ${ }^{18}$ reflect stronger regulatory oversight. We expect that under strong regulation, banks are encouraged to maintain high levels of capital and increase their regulatory capital ratios. Thus, we expect a positive sign for the coefficient of this variable in the determination of regulatory capital ratios.

We include the influence of the business cycle in the determination of regulatory capital ratios. According to previous studies (Ayuso et al., 2004; Jokipii and Milne, 2008; Lindquist, 2004), capital buffer and economic activity tend to be negatively related. Banks tend to decrease their capital buffer during economic booms and increase it during economic downturns. However, Berger et al. (1995) argue that banks with external growth strategies might increase their capital buffer during economic booms to exploit acquisition opportunities. We consider the annual growth rate of real GDP (GDP_GWT) as a proxy of the economic environment. The expected sign for the coefficient of this variable is ambiguous in the determination of regulatory capital ratios.

\subsubsection{Liquidity equation}

Berger and Bouwman (2009) shed light on the importance of bank market power in the ability to create liquidity. Market power can affect the availability of funds (Petersen and Rajan, 1995) and the distribution of the loan portfolio (Berger et al. 2005). Greater market power might enable banks to enhance their transformation activities by granting more loans and attracting more funds (i.e., deposits or market funding). Thus, market power is expected to positively affect liquidity creation and hence bank illiquidity. We consider the ratio of total assets of bank $i$ located in country $j$ to the total assets of the banking system in country $j$

\footnotetext{
${ }^{18}$ This index is the total number of affirmative answers to the following questions: (1) Is the minimum capital ratio requirement in line with the Basel guidelines? (2) Does the minimum ratio vary as a function of market risk? (3) Does the minimum ratio vary as a function of credit risk? (4) Does the minimum ratio vary as a function of operational risk? (5) Is there a simple leverage ratio required? (6) Are market values of loan losses not realized in accounting books deducted from capital? (7) Are unrealized losses in securities portfolios deducted? (8) Are unrealized foreign exchange losses deducted? (9) Are accounting practices for banks in accordance with International Accounting Standards? For each country in the sample, the possible changes in the answers to these questions over the 2000-2006 period were considered. Thus, for a given country, the value of the index might vary over time.
} 
$\left(M K T_{-} P O W\right)$ a proxy of bank market power. We expect a positive sign for the coefficient of this variable in the determination of bank illiquidity ${ }^{19}$.

Rauch et al. (2009a, 2009b) indicate the importance of monetary policy in the explanation of bank liquidity. When the central bank's policy rate is relatively low, credit supply increases, which positively affects bank illiquidity. In this study, we consider each country's central bank policy rate $(C B)$ a proxy of monetary policy. We expect a negative sign for the coefficient of this variable in the determination of bank illiquidity.

We also consider the impact of liquidity pressures on the interbank market. We use the spread between the one-month interbank rate and the policy rate of the central bank $\left(I B K 1 M_{-} C B\right)$ as a proxy of the liquidity pressures on the interbank market. Higher values of the spread reflect higher pressures on the interbank market, which make it more difficult for banks to access these sources of liquidity and, all else being equal, will therefore increase their liquidity risk (i.e., they might be unable to raise external funds). Consequently, we expect that higher values of the spread might negatively affect liquidity creation and bank illiquidity.

The macroeconomic environment is also likely to affect bank activities and investment decisions (Chen et al., 2010; Pana et al., 2010). For example, the demand for differentiated financial products is higher during economic booms and might improve banks' ability to expand their loan and securities portfolios at a higher rate. Similarly, economic downturns are exacerbated by the reduction in bank credit supply. We hence conjecture that banks might increase their maturity transformation activities and thus their illiquidity during economic booms. We use the annual growth rate of real GDP (GDP_GWT) as a proxy of the economic environment. We expect a positive sign for the coefficient of this variable in the determination of bank illiquidity.

Table 5 shows descriptive statistics of all explanatory variables.

\footnotetext{
${ }^{19}$ Bank size might also be a determinant of bank liquidity creation (Berger and Bouwman, 2009; Rauch et al., 2009). Large banks could create more liquidity than smaller banks because they have easier access to the lender of last resort and because they would be the first to benefit from the safety net. Therefore a positive relationship could be expected between bank size and illiquidity. We do not introduce this variable in the liquidity equation because it is highly correlated with our proxy of bank market power $\left(M K T \_P O W\right)$. In section 6, we perform three robustness checks. First, we orthogonalize our proxy of bank market power with our proxy of bank size. We introduce our proxy of bank size and the residual component of our proxy of bank market power. Second, we orthogonalize our proxy of bank size with our proxy of bank market power. We introduce our proxy of bank market power and the residual component of our proxy of bank size. Third, we replace our proxy of bank market power by our proxy of bank size. Our main results remain identical.
} 
[Insert Table 5]

\section{Results}

To test the impact of liquidity on bank regulatory capital beyond the determinants identified in the previous literature, we estimate a simultaneous equations system (system (1)). In the regulatory capital equation, we regress the bank regulatory capital ratio on a set of determinants from previous literature and on a proxy of liquidity. We use alternately two definitions of the regulatory capital ratio: the Tier 1 and 2 capital to risk weighted assets $\left(T 12_{-} R W A\right)$ and the Tier 1 capital to risk weighted assets $\left(T 1 \_R W A\right)$. The aim is to examine whether the results remain the same when considering the Tier 1 regulatory capital ratio rather than the Tier 1 and 2 regulatory capital ratio as banks might be managing the various components of regulatory capital differently. In the liquidity equation, we regress the proxy of liquidity on a set of determinants outlined in the previous literature. As proxies of liquidity, we use two indicators defined previously: the liquidity creation indicator ( $L C$, in systems (1.a) and $\left.\left(1 . \mathrm{a}^{\prime}\right)\right)$ and the inverse of the net stable funding ratio (I_NSFR, in systems (1.b) and $\left.\left(1 . b^{\prime}\right)\right)$. Table B. 1 and Table B.2 in Appendix B show the correlation coefficients among the explanatory variables in both the regulatory capital and the liquidity equations. In addition, in both the regulatory capital and the liquidity equations, the presumably endogenous bank-level indicators are replaced by their one-year lagged value ${ }^{20}$.

\subsection{The relationship between liquidity and regulatory capital ratios}

Table 6 shows the regression results.

[Insert Table 6]

The illiquidity variables $L C$ and $I \_N S F R$ have a significant and negative impact only on T12_RWA as the dependent variable. Banks tend to decrease their Tier 1 and 2 capital ratio when they face higher illiquidity. In contrast, they do not adjust their Tier 1 capital ratio.

\footnotetext{
${ }^{20}$ Previous empirical studies on capital buffer and liquidity highlight potential endogeneity with bank-level indicators. After testing for endogeneity (Hausman test), which confirms the presence of endogeneity and consistently with these studies, in both the regulatory capital and liquidity equations, we replace all bank-level explanatory variables by their one-year lagged value because they are presumably endogenous. Regarding our two variables of interest (i.e. capital and liquidity), which are not lagged, we address endogeneity by estimating a simultaneous GMM equation system.
} 
These results show that banks do not strengthen their solvency standards when they face higher illiquidity. The unexpected negative signs for our liquidity proxies might be explained as follows. Bank managers might consider certain liquid liabilities as stable and thus might be substituting stable liabilities to capital when facing higher illiquidity.

Regarding the other determinants of regulatory capital ratios and of liquidity, most of the findings are consistent with those obtained in previous studies. The most relevant factors to explain bank regulatory capital ratios are profitability $(R O E)$, the riskiness of bank assets (LLP_TLO) and the dividend payout ratio (DIV_PYRT). Thus, as hypothesized by Flannery and Rangan (2008) and Gropp and Heider (2010), more profitable banks or banks that distribute lower dividends tend to hold higher capital buffers, because they benefit from a better ability to accumulate capital from funds generated internally. In addition, consistent with Nier and Baumann (2006), banks increase their capital ratios when they face higher credit risk.

Focusing on the determinants of liquidity, regulatory capital ratios (T12_RWA and $\left.T 1 \_R W A\right)$ and the spread between the one-month interbank rate and the policy rate of the central bank (IBK1M_CB) are the most relevant factors. Consistently with the "financial fragility structure" (Diamond and Rajan, 2000, 2001) and the "crowding-out of deposits" (Gorton and Winton, 2000) theories, higher regulatory capital ratios are associated with lower liquidity creation and illiquidity. According to the "financial fragility structure" theory, this result might indicate that banks benefit from their informational advantage, which creates an agency problem. Banks are likely to extort rents from depositors. Consequently, banks must win depositors' confidence by adopting a fragile financial structure with a large share of liquid deposits. Financial fragility favors liquidity creation because it allows banks to collect more deposits and grant more loans. In addition, from the "crowding-out of deposits" theory, higher capital ratios shift investors' funds from relatively liquid deposits to relatively illiquid bank capital. Thus, the higher are banks' capital ratios, the lower is their liquidity creation. In addition, perhaps surprisingly, the current findings highlight that an increase in the spread between the one-month interbank rate and the policy rate of the central bank is associated with higher illiquidity. Consistent with Berger and Bouwman (2012), our results also indicate that monetary policy $(C B)$ is not a relevant factor to explain bank liquidity ${ }^{21}$.

\footnotetext{
${ }^{21}$ Berger and Bouwman (2012) show that during normal times, monetary policy does not seem to have a significant effect on total liquidity creation by medium and large banks and that, for small banks, even if a loosening of monetary policy is associated with an increase in liquidity creation, this effect is economically small.
} 
In summary, the results show that banks do not strengthen their solvency standards when they face higher illiquidity. They do not adjust their Tier 1 capital ratio and they actually decrease their Tier 1 and 2 capital ratio when they face higher illiquidity. Nevertheless, the definition of our liquidity measures can be adjusted in the U.S. case. Indeed, Harvey and Spong (2001) and Saunders and Cornett (2006) emphasize the importance of core deposits for U.S. banks. Core deposits are defined as the sum of demand deposits, saving deposits and time deposits lower than US\$100,000. These deposits are to a great extent derived from a bank's regular customer base and are therefore typically the most stable and least costly source of funding for banks (Harvey and Spong, 2001). Thus, it might be relevant to adopt an alternative definition for stable deposits by considering core deposits for U.S. banks. Consequently, we compute an alternative liquidity proxy by modifying the denominator of the inverse of the net stable funding ratio (I_NSFR). More precisely, we consider the sum of core deposits and other stable funding as a proxy of the available amount of stable funding ${ }^{22}$. This liquidity proxy is defined as the $C F R$ variable. It is computed as follows for U.S. banks:

$$
\begin{aligned}
& 0 *(\text { cash }+ \text { interbank assets }+ \text { short-term marketable assets }) \\
& +0.5 *(\text { long-term marketable assets }+ \text { customer acceptances }) \\
& +0.85 * \text { consumer loans } \\
\text { CFR }=\text { Required amount of stable funding }= & +1 *(\text { commercial loans }+ \text { other loans }+ \text { other assets }+ \text { fixed assets }) \\
\hline \text { Core deposits }+ \text { Stable funding } & +0 * \text { (short-term market debt }+ \text { other short-term liabilities }) \\
& +1 * \text { (long-term liabilities }+ \text { equity })
\end{aligned}
$$

\subsection{The impact of liquidity on regulatory capital ratios separately for European and} U.S. banks: The importance of core deposits for U.S. banks

To delve deeper into the relationship between liquidity and regulatory capital ratios, we run regressions separately for European and U.S. banks by also considering the $C F R$ variable for U.S. banks. Table 7 and Table 8 show the regression results. The $C F R$ variable is included in systems (1.c) and (1.c') in Table 8. In system (1.c), the $K_{-} R W A$ variable is the Tier 1 and 2 capital to total risk weighted assets $\left(T 12 \_R W A\right)$. In systems $\left(1 . \mathrm{c}^{\prime}\right)$, the $K_{-} R W A$ variable is the Tier 1 capital to total risk weighted assets $\left(T 1 \_R W A\right)$.

[Insert Tables 7 and 8]

\footnotetext{
${ }^{22}$ The average share of core deposits to total deposits over the $2000-2006$ period is $79 \%$ for the U.S. banks included in the sample. However, there is a high heterogeneity: the standard deviation of this ratio is $13.5 \%$.
} 
Regarding European banks, while the coefficient of $I_{-} N S F R$ is significantly negative only when the total regulatory capital ratio is the dependent variable, the coefficient of $L C$ is significantly negative for both definitions of regulatory capital ratios as the dependent variables. These results emphasize that, instead of strengthening their solvency standards, European banks reduce their regulatory capital ratios when they face higher illiquidity.

Focusing on U.S. banks, for both definitions of regulatory capital ratios, all the coefficients of the proxies of liquidity are significantly negative. These results show that, similarly to European banks, U.S. banks decrease their regulatory capital ratios when they face higher illiquidity even when considering a measure of bank liquidity that focuses more closely on core deposits.

\subsection{The impact of bank size and access to external funding on the relationship} between liquidity and regulatory capital ratios

By running separate regressions for U.S. and European banks, the results show that, regardless of their institutional environment, banks do not strengthen their regulatory capital ratios when they face higher illiquidity. However, depending on their size, the ability of banks to access external funding is presumably different. Large banks might benefit from a reputational advantage, possibly providing them a broader access to financial markets. This is likely to affect the causal link that goes from bank illiquidity to capital ${ }^{23}$. Furthermore, large and small banks might have different scope of activities and contrasting business models.

Following the literature, a bank is considered small if its total assets are below US\$1 billion. In Table $2^{24}$, the data show that small banks both in Europe and in the United States are on average more focused on traditional intermediation activities than large banks. Small banks hold significantly more average shares of loans and deposits in total assets than large banks. Therefore, we run regressions separately for large and small banks, still separating European and U.S. banks (Table 9$)^{25}$.

\footnotetext{
${ }^{23}$ Berger and Bouwman (2009) also argue that the "financial fragility structure", the "deposit crowding-out" and the "risk absorption" effects might affect differently the causal link that goes from bank capital to liquidity creation depending on bank size. They expect that both the "financial fragility structure" and "deposit crowdingout" effects are likely to be relatively strong for small banks. Indeed small banks deal more with entrepreneurialtype small businesses, where the close monitoring highlighted in Diamond and Rajan $(2000,2001)$ is important. In addition, small banks tend to be more funded by deposits, so that capital may "crowd out" deposits as in Gorton and Winton (2000). This effect is likely to be relatively weak for large banks that can more easily access market funding.

${ }^{24}$ See Section 3.1.

${ }^{25}$ Only the results obtained for the variables of interest are reported in Table 9. Detailed results are available upon request.
} 
In addition, following the subprime crisis, most regulatory authorities emphasize the importance of "systemically important financial institutions". The Federal Reserve qualifies a bank as "significant" if it holds US\$50 billion or more in total consolidated assets (FED, $2011)^{26}$. Using this criterion, we run regressions separately for European and U.S. banks on two sub-samples of banks: the very large (i.e., "significant") banks (total assets above US\$50 billion) and the other large banks (total assets below US\$50 billion and above US\$1 billion). Table 10 shows the regression results ${ }^{27}$.

[Insert Table 10]

Regarding European banks, for both large and small banks, banks do not strengthen their regulatory capital ratios when they face higher illiquidity (Table 9). However, because the sample of European banks includes a relatively low number of small banks (i.e., only 37 banks), the results for small European banks might not be as reliable as those for large banks. For large U.S. banks (Table 9), for both definitions of regulatory capital ratios, all the liquidity variables have a significantly negative effect on bank regulatory capital ratios ${ }^{28}$. By contrast, for small U.S. banks, the $L C$ and $I_{-} N S F R$ variables are not significant to explain bank regulatory capital ratios. Besides, whereas the coefficient of $C F R$, a measure of liquidity that focuses more closely on core deposits, is significantly negative for large U.S. banks, it is significantly positive for small U.S. banks with both definitions of regulatory capital. Thus, small banks increase their regulatory capital ratios when they face higher illiquidity, as measured by the $C F R$ variable. These findings suggest that when small banks face higher

\footnotetext{
${ }^{26}$ The term 'significant is used in the credit exposure reporting provisions of the Dodd-Frank Act, which apply to bank holding companies and foreign banks that are treated as a bank holding company and that have US\$50 billion or more in assets (FED, 2011).

${ }^{27}$ Only the results obtained for the variables of interest are reported in Table 10. Detailed results are available upon request.

${ }^{28}$ Regarding the causal link that goes from bank capital to liquidity creation, our results, which are available upon request, show that this relationship is insignificant for large banks. This finding is consistent with the results of Berger and Bouwman (2009) based on a liquidity creation indicator ignoring off-balance sheet activities. However, they find a positive and significant relationship between capital and liquidity creation for large banks when they consider a liquidity creation measure that includes off-balance sheet activities. In contrast with Berger and Bouwman (2009), we do not find a significant and negative relationship between bank capital and liquidity creation for small banks. Our sample only includes listed banks and ignores a large number of small privately owned banks. The results are therefore not directly comparable but suggest that publicly traded banks which are more closely monitored by market participants behave differently than privately owned ones.
} 
illiquidity, they increase their regulatory capital ratios, presumably to secure access to external sources of liquidity if necessary.

Regarding our findings for very large banks, our sample includes 20 very large financial institutions and 197 other large banks in the United States (i.e., 3\% and 34\% of the sample of U.S. banks, respectively) and 56 very large financial institutions and 114 other large banks in Europe (i.e., 27\% and 55\% of the sample of European, respectively). For both U.S. and European very large banks (Table 10), there is no significant positive link between regulatory capital ratios and illiquidity. However, because the sample includes a relatively low number of very large banks, the results might not be as reliable as those for other large banks. When we consider U.S and European other large banks, for both definitions of regulatory capital ratios, all the liquidity variables have a significantly negative effect on bank regulatory capital ratios.

On the whole, only small U.S. banks increase their regulatory capital ratios when facing higher illiquidity considering a measure of bank illiquidity that focuses more closely on core deposits. These findings suggest that bank managers might be rationally targeting a liquidity ratio different from the one proposed by Basel III to adjust their regulatory capital ratios. Presumably, large banking institutions might underestimate liquidity risk because of their too-big-to-fail position. If bank executives believe they can systematically have priority access to liquidity for safety net and systemic risk considerations, such institutions will not adjust their regulatory capital ratios accordingly. However, large institutions might also be managing liquidity differently, with more sophisticated off-balance sheet instruments. Because a detailed breakdown of off-balance sheets is not available in standard databases, we solely consider the liquidity profile of banks stemming from their on-balance sheet positions. Therefore, our liquidity measures will either underestimate or overestimate a bank's actual exposure to liquidity risk depending on the extent of its net off-balance sheet commitments (i.e., short or long net positions). This could alter our results for large banks because they are generally more involved in off-balance sheet activities, and specifically in sophisticated instruments, than small banks. If the actual exposure of large banks to liquidity risk is higher than the one captured through their on-balance sheet operations, the results would still be consistent. However, if their actual exposure is lower because they are using off-balance sheet instruments to hedge part of their liquidity risk, the results for large banks will merely indicate that such institutions manage their liquidity differently and not necessarily that they are taking advantage of their too-big-to-fail position. 


\section{Robustness checks}

We perform several robustness checks, still considering European and U.S. banks separately according to their size. We run regressions separately for 2 groups: large and small banks. Appendix C presents regression results ${ }^{29}$.

\subsection{Including banks with regulatory capital ratios below minimum requirements}

We further check the robustness of our results by including the banks with regulatory capital ratios below the minimum requirements. For European banks, the number of observations remains unchanged for the group of small banks but 13 observations are added for the group of large banks. For U.S. banks, 2 observations are added for the sub-sample of large banks and 4 observations for the sub-sample small banks. In all cases, the results are consistent with those previously obtained ${ }^{30}$.

\subsection{Considering Tier 1 and 2 regulatory capital buffer}

We further investigate the robustness of our results by considering bank regulatory capital buffer instead of bank regulatory capital ratios. We take in account that regulators set the minimum requirement at $8 \%$, except in Cyprus where it is equal to $10 \%$ and in the United Kingdom where it is equal to $9 \%$ following Jokipii and Milne $(2008)^{31}$. In addition, in Germany, regulatory minimum requirement is set to $12.5 \%$ for newly established banks in the first two years of business. However, such banks are not included in the sample of German banks. We perform this robustness check only for Europeans banks considering the Tier 1 and 2 regulatory capital ratio. Indeed, as the minimum requirement for this regulatory capital ratio is set to $8 \%$ in the United States, considering Tier 1 and 2 regulatory capital buffer or the Tier 1 and 2 risk weighted capital ratio leads to the same results. Similarly, as the minimum requirement for the Tier 1 risk weighted capital ratio is set to $4 \%$ in all countries, considering

\footnotetext{
${ }^{29}$ In all the tables, we only report the results obtained for the variables of interest. Detailed results are available upon request.

${ }^{30}$ Results are available upon request.

${ }^{31}$ In the United Kingdom, the Financial Stability Authority considers two capital ratios: the trigger ratio and the higher target ratio. The trigger ratio corresponds to the regulatory minimum risk weighted capital ratio. The higher target ratio is set above the trigger ratio, resulting in higher levels of capital required by the regulators for individual banks. Jokipii and Milne (2008) consider a 9\% requirement for UK banks. To deal with this issue and following Jokipii and Milne (2008), the regulatory minimum risk weighted capital ratio is set at $9 \%$ in this study for UK banks.
} 
Tier 1 regulatory capital buffer or the Tier 1 risk weighted capital ratio leads to the same results. Regression results considering only European banks are shown in Table C.2. The results are consistent with those previously obtained with the Tier 1 and 2 regulatory capital ratio.

\section{3. "True commercial banks"}

Following Berger and Bouwman (2009), we also run our estimations on a sub-sample limited to "true commercial banks". We impose the following restrictions. We exclude a bank if it is very small (with total assets below US\$25 million) and if it has consumer loans exceeding 50\% of total assets. Berger and Bouwman (2009) also delete a bank if it (1) has no loans outstanding; (2) has zero deposits; (3) has zero or negative equity capital. However, we have no such banks in our sample. Furthermore, they consider two other criteria and delete a bank if it has unused commitments exceeding four times of total assets and if it resembles a thrift (residential real estate loans exceeding $50 \%$ of total assets). Due to data limitation we do not consider these two additional criteria. For European banks, we delete 81 observations for large banks and 38 observations for small banks For U.S. banks, we delete 58 observations for large banks and 161 observations for small banks. In all cases, the main conclusions are consistent with those previously obtained on our full sample of banks (Table C.3).

\subsection{Introducing bank size in the liquidity equation}

Large banks could create more liquidity than small banks because they have easier access to the lender of last resort and because they would be the first to benefit from the safety net. Therefore a positive relationship could be expected between bank size and illiquidity. As an additional robustness check, we introduce a proxy of bank size in the liquidity equation. The natural logarithm of total assets $\left(L N_{-} T A\right)$ is considered as a proxy of bank size. As this variable is highly correlated with our proxy of bank market power (MKT_POW), we perform three robustness checks. First, we orthogonalise our proxy of bank market power with our proxy of bank size. We introduce our proxy of bank size and the residual component of our proxy of bank market power (Table C.4). Second, we orthogonalise our proxy of bank size with our proxy of bank market power. We introduce our proxy of bank market power and the residual component of our proxy of bank size (Table C.5). Third, we include our proxy of 
bank size in the two equations and we delete our proxy of market power in the liquidity equation (Table C.6). In all cases, our results are consistent with those previously obtained.

\subsection{A measure of liquidity creation adjusted for equity}

The regression specification is inspired by the theories of bank liquidity creation. These theories argue that banks create liquidity when illiquid assets are transformed into liquid liabilities but not when they are transformed into illiquid claims such as equity. The theories also emphasize that equity might affect a bank's ability to create liquidity. A potential concern about the regression specification is that current bank equity is included in both the liquidity creation indicator and the regulatory capital ratios. To address this issue, following Berger and Bouwman (2009), we compute an alternative liquidity creation measure by excluding equity $L C_{-} E E$. This measure does not penalize banks for funding part of their activities with equity capital. As a result, the measured amount of liquidity creation is higher for all banks, and this increase is larger for banks holding more capital (Table C.7). On the whole, our main conclusions are consistent with those previously obtained with the $L C$ variable.

\subsection{Alternative weights for stable deposits in the inverse of the net stable funding ratio}

To determine the robustness of the results for the I_NSFR variable, we change the weight of 0.7 for demand and saving deposits. We alternately consider three other weights to determine whether the results can be affected by the extent of deposits considered stable. The first weight, 0.5 ( I_NSFR_D05), is the minimum weight set by the Basel Committee on Banking Regulation and Supervision for stable demand and saving deposits. The second, 0.85 (I_NSFR_D085), is the maximum weight set by the Basel Committee on Banking Regulation and Supervision for stable demand and saving deposits. The third, 1, is the extreme case considering all demand and saving deposits as stable. Explicit deposit insurance systems and implicit government guarantee of deposits mitigate the risk of run on deposits and strengthen their stability (I_NSFR_D1). Again, our main conclusions are consistent with those previously obtained with the $I \_N S F R$ variable (Table C.8). 


\subsection{Alternative liquidity proxies}

We further examine the robustness of our results by considering other definitions for liquidity proxies. First, we use an alternative specification of the liquidity creation indicator by computing the ratio of illiquid assets to illiquid liabilities ( $\left.I A_{-} I L\right)$ as defined by Berger and Bouwman (2009). Second, we use a liquidity proxy based on the "liquidity transformation gap" (also called LT Gap) as Deep and Schaefer (2004) suggest. The LT Gap is the difference between liquid liabilities and liquid assets held by a bank, scaled by its total assets. In their work, they deem all the assets and the liabilities that mature within one year liquid. Using this definition of illiquid assets and liabilities of Deep and Schaefer (2004), we compute the "liquidity transformation ratio" (also called "LT Ratio", LTR) as the ratio of illiquid assets (i.e., total loans, long term marketable assets, other assets and net fixed assets) to illiquid liabilities (i.e., time deposits, long term market funding and equity). Finally, we use an alternative specification of the $C F R$ variable based on the "financing gap" of Saunders and Cornett (2006). The "financing gap" is the difference between average loans and core deposits. Using this indicator, the core deposit ratio $(C D R)$ is the ratio of total loans to total core deposits. As for the $C F R$ variable, the core deposit ratio variable is only calculated for U.S. banks, as core deposits can only be identified for U.S. banks (Table C.9). On the whole, the results confirm the conclusions previously obtained.

\subsection{Alternative definitions of small U.S. banks}

Following the literature, a bank is considered small if its total assets are below US\$1 billion. This definition of small banks conforms in the U.S. to the usual notion of "community banks" that primarily create liquidity by transforming locally generated deposits into local loans on the balance sheet. However, all the banks considered in our study are listed on a stock exchange. Such institutions are very different and have unequal access to financial markets. Thus, as a robustness check, we consider other criteria to define small U.S. banks ${ }^{32}$. First, following FDIC (2012), we consider that while community banks are traditionally defined strictly in terms of their size, a more nuanced model should be chosen depending on the amount of loans and core deposits. Banks with total assets below US\$1 billion should not

\footnotetext{
${ }^{32}$ We do not apply these criteria in the European case because listed banks in Europe are on average larger. Thus, there is only 37 European banks in our sample with total assets below US\$1 billion. Besides, the notion of "community bank" is specific to the U.S..
} 
be automatically included if they lack high loan levels and core funding. Thus, we include only banks with total assets below US\$1 billion that have a ratio of total loans to total assets that exceeds $33 \%$ and a ratio of total core deposits to total assets that exceeds $50 \%{ }^{33}$ (see FDIC (2012)). Our results are consistent with those previously obtained (Table C.10). Indeed, both the $L C$ and $I$ NSSFR variables are not significant to explain bank regulatory capital ratios whereas the $C F R$ variable has a significantly positive effect on both regulatory capital ratios. Besides, the level of significance of the $C F R$ variable is higher and the associated coefficient is twice the one obtained for banks with total assets below US\$1 billion.

Second, because our aim is to focus on banks with a restricted access to financial markets, we consider only the "very small banks" which are expected to have the most restricted access to financial markets. Following FDIC (2009), a bank is considered very small if its total assets is lower than US\$500 million. Our results are consistent with those previously obtained (Table C.11). We still find that the $C F R$ variable has a significantly positive effect on both regulatory capital ratios. In addition, the $I_{-} N S F R$ variable has also a significantly positive effect on the regulatory capital ratios.

Third, we consider other criteria to define banks with limited access to financial markets. We only include in our sample of small U.S. banks, banks with total assets below US\$ 1 billion which do not issue subordinated debt (null subordinated debt) and whose reliance on market funding is relatively low (ratio of market debts ${ }^{34}$ to total debt lower than the median calculated on the whole sample of U.S. banks (11.7\%)) (Table C.12). We still find that the $C F R$ variable has a significantly positive effect on both regulatory capital ratios. The level of significance of the $C F R$ variable is higher and the associated coefficient is twice the one obtained for banks with total assets below US\$1 billion. Besides, the $I$ NSFR variable has also a significantly positive effect on the regulatory capital ratios. Thus, small U.S. banks (with total assets below US\$1 billion) with a limited reliance on financial markets improve their solvency more strongly than other small banks when they face higher illiquidity as defined in the Basel III accords.

\footnotetext{
${ }^{33}$ These criteria are applied to large banks in FDIC (2012) to broaden the sample of community banks. In our case, we apply these criteria to small banks to ensure that they have a business model corresponding to community banks.

${ }^{34}$ Market debts correspond to short and long term borrowings, and subordinated debt. Short-term borrowings include bank overdrafts, short-term debts and borrowings, repurchase agreements (repos) and reverse repos, short-term portion of long-term borrowings, current obligations under capital (finance) leases trust receipts, bills payable, bankers acceptances, and current portion of hire purchase creditors. Long-term borrowings include all interest-bearing financial obligations that are not current, convertible, redeemable, retractable debentures, bonds, loans, mortgage debts, sinking funds, long-term bank overdrafts and capital (finance) lease obligations. They exclude short-term portion of long term debt, pension obligations, deferred tax liabilities and preferred equity.
} 


\section{Concluding remarks}

The purpose of this paper is to study the relationship between bank regulatory capital buffer and liquidity. Building on previous studies indicating that capital and liquidity are presumably jointly determined, we consider a simultaneous equations model to investigate the impact of bank liquidity measured from on-balance sheet positions on regulatory capital buffer beyond the determinants considered in the existing literature. Specifically, we question whether banks maintain or strengthen their regulatory capital buffer when they face lower liquidity because regulatory requirements regarding liquidity have not yet been implemented.

The main results show that banks decrease their regulatory capital when they create more liquidity (i.e., when they fund larger portions of illiquid assets with liquid liabilities) or when they face higher illiquidity as defined in the Basel III accords. Nevertheless, the definition of stable funding might be adjusted in the U.S. case. By using an alternative indicator of liquidity that focuses more closely on core deposits for U.S. banks, the results show that small U.S. banks do actually strengthen their solvency standards when they face higher illiquidity.

These findings support the need to implement minimum liquidity ratios concomitant to capital ratios, as stressed by the Basel Committee on Banking Regulation and Supervision, but they also cast doubt on the accuracy of the current framework. Adding liquidity ratios to capital ratios might be more relevant for large banking institutions than for small banks. Presumably, large banking institutions might underestimate liquidity risk because of their toobig-to-fail position. However, large institutions might also be managing liquidity differently, with more sophisticated off-balance sheet instruments.

Moreover, the definition and measurement of liquidity must be further clarified under a global regulatory framework. Regulators need to determine what type of liquid liabilities should be considered stable for a deeper regulatory definition of the notion of core or stable deposits. These findings also raise questions regarding the implementation of uniform liquidity requirements to all types of banks if large banking institutions either behave differently because of their too-big-to-fail position or are able to manage their liquidity differently. 


\section{References}

Alfon, I., Argimon, I., Bascuñana-Ambrós, P., 2004. What determines how much capital is held by UK banks and building societies? Financial Service Authority, Working Paper.

Allen, F., Gale, D., 2004. Financial intermediaries and markets. Econometrica, 72, 10231061.

Angora, A., Roulet, C., 2011, Transformation risk and its determinants: A new approach based on the Basel III liquidity management framework, Working Paper, Université de Limoges.

Ayuso, J., Pérez, D., Saurina, J., 2004. Are capital buffers pro-cyclical? Evidence from Spanish panel data. Banco de España, Journal of Financial Intermediation, 13, 249-264.

Bank of International Settlements, 2009. International framework for liquidity risk, measurement and monitoring. Consultative Document.

Barth, J. R., Caprio, G., Levine, R., 2007. Bank regulation and supervision. World Bank Database.

Bhattacharya, S., Thakor. A. V., 1993. Contemporary Banking Theory. Journal of Financial Intermediation, 3, 2-50.

Berger, A. N., Herring, R., Szegö, G., 1995. The role of capital in financial institutions. Journal of Banking and Finance, 19, 393-430.

Berger, A. N., Miller, N. H., Petersen, M. A., Rajan, R. G., Stein, J. C., 2005. Does function follow organizational form? Evidence from the lending practices of large and small banks. Journal of Financial Economics, 76, 237-269.

Berger, A. N., DeYoung, R., Flannery, M. J., Lee, D., Öztekin, Ö., 2008. How do large banking organizations manage their capital ratios? Journal of Financial Services Research, 34, 123-149.

Berger, A. N., Bouwman, C. H. S., 2009. Bank liquidity creation. Review of Financial Studies, 22, 3779-3837.

Berger, A. N., Bouwman, C. H. S., Kick, T., Schaeck, K., 2012. Bank risk taking and liquidity creation following regulatory interventions and capital support, Working Paper, March 15, SSRN.

Berger, A. N., Bouwman, C. H. S., 2012. Bank liquidity creation, monetary policy, and financial crises. Working Paper.

Bikker, J., Metzemakers, P., 2004. Is bank capital procyclical? A cross-country analysis. Netherlands Central Bank Research Department, Working Paper. 
Bryant, J., 1980. A model of reserves, bank runs, and deposit insurance. Journal of Banking and Finance, 4, 335-344.

Chen, Y. K., Kao, L. F., Shen, C. H., Yeh, C. Y., 2010. Bank liquidity risk and performance. International Monetary Fund, Working Paper No. 09/52.

Deep, A., Schaefer, G., 2004. Are banks liquidity transformers? Harvard University Faculty Research, Working Paper.

Diamond, D.W., Dybvig, P. H., 1983. Bank runs, deposit insurance, and liquidity. Journal of Political Economy, 91, 401-419.

Diamond, D. W., Rajan, R. G., 2000. A theory of bank capital. Journal of Finance, 55, 24312465.

Diamond, D. W., Rajan, R. G., 2001. Liquidity risk, liquidity creation, and financial fragility: A theory of banking. Journal of Political Economy, 109, 287-327.

FDIC, 2012. Community banking by the numbers, The FDIC Community Banking Research Project, FDIC Future of Community Banking Conference (February 16, 2012).

FDIC, 2009. Bank holding companies and change in bank control, Regulation Y, Small bank holding company policy Statement, Part-225-Appendix C.

Federal Register, 2011. Proposed rules. Federal Reserve, 76, 7731-7740.

Flannery, M. J., Rangan, K. P., 2008. What caused the bank capital build-up of the 1990s? Review of Finance, 12, 391-429.

Fonseca, A.R., González, F., 2010. How bank capital buffers vary across countries: The influence of cost of deposits, market power and bank regulation. Journal of Banking and Finance, 34, 892-902.

Fungacova, Z., Weill, L., and Zhou, M., 2010, Bank capital, liquidity creation and deposit insurance, BOFIT discussion paper $\mathrm{n}^{\circ} 17 / 2010$.

Gropp, R., Heider, F., 2010. The determinants of capital structure. Review of Finance, 14, 587-622.

Gorton, G., Winton, A., 2000. Liquidity provision, bank capital, and the macroeconomy. University of Minnesota, Working Paper.

Hall, A.R., 2005. Generalized method of moments. Oxford University Press, Oxford.

Harvey, J., Spong, K., 2001. The decline in core deposits: What can do banks? Federal Reserve Bank of Kansas City, Working Paper.

Horvath, R., Jakub S., Weill L., 2012, Bank capital and liquidity creation: Granger causality evidence, Working Paper, Charles University in Prague. 
Imbierowicz, B., Rauch, C., 2012, The Relationship between Liquidity Risk and Credit Risk in Banks, Working Paper, April 11, SSRN.

Jokipii, T., Milne, A., 2008. The cyclical behavior of European bank capital buffers. Journal of Banking and Finance, 32, 1440-1451.

Jokipii, T., Milne, A., 2011. Bank capital buffer and risk adjustment decisions. Journal of Financial Stability, 7, 165-178.

Kashyap, A. K., Rajan, R. G., Stein, J. K., 2002. Banks as liquidity providers: An explanation for the coexistence of lending and deposit taking. Journal of Finance, 58, 33-73.

Laeven, L. A., Levine, R., 2008. Bank governance, regulation and risk taking. NBER, Working Paper.

Lindquist, K., 2004. Banks' buffer capital: How important is risk? Journal of International Money and Finance, 23, 493-513.

Matz, L., Neu, P., 2007. Liquidity risk: Measurement and management. Wiley Finance.

Nier, E., Baumann, U., 2006. Market discipline, disclosure and moral hazard in banking. Journal of Financial Intermediation, 15, 332-361.

Pana, E., Park, J., Query, T., 2010. The impact of mergers on liquidity creation. Journal of Risk Management in Financial Institutions, 4, 74-96.

Petersen, M. A., Rajan, R. G., 1995. The effect of credit market competition on lending relationships. Quarterly Journal of Economics, 110, 407-443.

Poorman, F., Blake, J., 2005. Measuring and modeling liquidity risk: New ideas and metrics. Financial Managers Society Inc., Working Paper.

Rauch, C., Steffen, S., Hackethal, A., Tyrell, M., 2009a. Determinants of bank liquidity creation: Evidence from savings banks. Working Paper.

Rauch, C., Steffen, S., Hackethal, A., Tyrell, M., 2009b. Savings banks, liquidity creation and monetary policy. Working Paper.

Repullo, R., 2004. Capital requirements, market power, and risk taking in banking. Journal of Financial Intermediation, 13, 156-182.

Saunders, A., Cornett, M. M., 2006. Financial institutions management: A risk management approach. McGraw-Hill Boston, Working Paper.

Shehzad, C; T., De Haan, J., Scholtens, B., 2010. The impact of bank ownership concentration on impaired loans and capital adequacy. Journal of Banking and Finance, 34, 399-408.

Stolz, S., Wedow, M., 2011. Banks' regulatory capital buffer and the business cycle: Evidence for Germany. Journal of Financial Stability, 7, 98-110. 
Von Thadden, E.-L., 2004. Bank Capital Adequacy Regulation under the New Basel Accord. Journal of Financial Intermediation, 13, 90-95.

Table 1. Distribution of U.S. and European publicly traded commercial banks

\begin{tabular}{|l|c|c|c|}
\cline { 2 - 4 } \multicolumn{1}{c|}{} & $\begin{array}{c}\text { Banks } \\
\text { available in } \\
\text { Bloomber }\end{array}$ & $\begin{array}{c}\text { Banks included in } \\
\text { our final sample }\end{array}$ & $\begin{array}{c}\text { Total assets of banks in final } \\
\text { sample / total assets of the } \\
\text { banking system (\%) }\end{array}$ \\
\hline United States & $\mathbf{6 4 5}$ & $\mathbf{5 7 4}$ & $\mathbf{6 6 . 4}$ \\
\hline Europe & $\mathbf{2 2 5}$ & $\mathbf{2 0 7}$ & $\mathbf{6 0 . 4}$ \\
\hline Austria & 8 & 8 & 57.3 \\
Belgium & 4 & 3 & 80.3 \\
Cyprus & 4 & 4 & 69.7 \\
Denmark & 44 & 38 & 60.6 \\
Finland & 2 & 2 & 71.2 \\
France & 22 & 22 & 62.1 \\
Germany & 15 & 14 & 40.1 \\
Greece & 12 & 12 & 80.6 \\
Iceland & 2 & 2 & 66.3 \\
Ireland & 3 & 3 & 31.3 \\
Italy & 24 & 22 & 59.6 \\
Liechtenstein & 2 & 2 & 50.1 \\
Malta & 4 & 4 & 32.5 \\
Netherlands & 2 & 2 & 47.6 \\
Norway & 23 & 20 & 70.3 \\
Portugal & 6 & 6 & 55.3 \\
Spain & 15 & 15 & 64.4 \\
Sweden & 4 & 4 & 72.6 \\
Switzerland & 22 & 18 & 74.8 \\
United Kingdom & 7 & 6 & 61.5 \\
\hline
\end{tabular}

Source: Bloomberg, European Central Bank, Bank of England, National Bank of Switzerland, Sveriges Riskbank, Danmarks Nationalbank, Central Bank of Iceland, FDIC and Finance Norway. To deal with the issue of sample representativeness, we compare aggregate total assets of banks included in the final sample (i.e., U.S. and European publicly traded commercial banks) with aggregate total assets of the whole banking system. From 2000 to 2006, we compute the ratio of aggregate total assets of banks included in the final sample to aggregate total assets of the whole banking system. This table reports the average value of this ratio country by country. 
Table 2. Summary descriptive statistics of the sample of U.S. and European listed commercial banks, on average, from 2000 to 2006

\begin{tabular}{|c|c|c|c|c|c|c|c|c|}
\hline & $\begin{array}{l}\text { Total assets in } \\
\text { US\$ billion }\end{array}$ & $\begin{array}{l}\text { Total loans / } \\
\text { total assets }\end{array}$ & $\begin{array}{c}\text { Total deposits / } \\
\text { total assets }\end{array}$ & $\begin{array}{c}\text { Loan loss } \\
\text { provisions / } \\
\text { total loans }\end{array}$ & $\begin{array}{c}\text { Tier } 1 \text { capital / } \\
\text { total as sets }\end{array}$ & $\begin{array}{c}\text { Tier } 1 \text { and } 2 \\
\text { capital / RWA }\end{array}$ & ROA & $\begin{array}{c}\text { Total interest } \\
\text { income / total } \\
\text { income }\end{array}$ \\
\hline \multicolumn{9}{|c|}{ All banks } \\
\hline Mean & 42.5 & 65.4 & 70.7 & 0.4 & 8.4 & 13.4 & 0.9 & 72.0 \\
\hline Median & 1.0 & 67.2 & 76.1 & 0.3 & 7.9 & 12.6 & 1.0 & 75.6 \\
\hline $\operatorname{Max}$ & 2176.5 & 95.1 & 93.9 & 6.7 & 35.2 & 34.0 & 6.9 & 100.0 \\
\hline Min & 0.02 & 4.8 & 4.1 & -1.2 & 2.1 & 8.0 & -13.3 & 4.7 \\
\hline Std. Dev. & 180.0 & 14.2 & 17.0 & 0.5 & 3.3 & 3.3 & 0.9 & 15.6 \\
\hline \multicolumn{9}{|c|}{ Large U.S. banks } \\
\hline Mean & 34.9 & 63.5 & 73.9 & 0.4 & 8.0 & 13.2 & 1.1 & 72.8 \\
\hline Median & 2.8 & 65.5 & 75.4 & 0.3 & 7.5 & 12.5 & 1.2 & 74.9 \\
\hline Max & 1962.5 & 93.2 & 92.1 & 4.7 & 28.5 & 30.1 & 5.7 & 99.5 \\
\hline Min & 1.00 & 4.8 & 28.0 & -0.6 & 0.1 & 5.1 & -13.3 & 16.6 \\
\hline Std. Dev. & 157.3 & 12.5 & 9.8 & 0.4 & 2.6 & 2.8 & 0.8 & 13.1 \\
\hline \multicolumn{9}{|c|}{ Small U.S. banks } \\
\hline Mean & 0.5 & 67.6 & 90.7 & 0.3 & 9.3 & 14.2 & 0.9 & 79.9 \\
\hline Median & 0.4 & 68.8 & 92.1 & 0.3 & 8.7 & 13.2 & 1.0 & 81.5 \\
\hline Max & 1.0 & 93.0 & 100.0 & 5.9 & 59.9 & 36.0 & 6.9 & 98.9 \\
\hline Min & 0.0 & 6.9 & 52.7 & -0.7 & 2.5 & 8.2 & -13.3 & 20.6 \\
\hline Std. Dev. & 0.2 & 11.4 & 7.1 & 0.4 & 3.8 & 3.6 & 0.9 & 10.3 \\
\hline $\begin{array}{l}\text { Test statistic \& } \\
\% \text { level }\end{array}$ & $\begin{array}{c}-10.12 * * * \\
(0.00)\end{array}$ & $\begin{array}{c}10.27 * * * \\
(0.00)\end{array}$ & $\begin{array}{c}22.30 * * * \\
(0.00)\end{array}$ & $\begin{array}{c}-1.23 * * * \\
(0.00)\end{array}$ & $\begin{array}{c}14.07 * * * \\
(0.00)\end{array}$ & $\begin{array}{c}7.84 * * * \\
(0.00)\end{array}$ & $\begin{array}{c}-9.64 * * * \\
(0.00)\end{array}$ & $\begin{array}{c}18.15 * * * \\
(0.00)\end{array}$ \\
\hline \multicolumn{9}{|c|}{ Large European banks } \\
\hline Mean & 145.2 & 63.2 & 47.6 & 0.5 & 6.6 & 11.5 & 0.7 & 56.4 \\
\hline Median & 14.6 & 65.4 & 48.1 & 0.4 & 6.0 & 11.3 & 0.7 & 58.4 \\
\hline Max & 2176.5 & 95.1 & 93.6 & 6.7 & 26.0 & 25.9 & 3.8 & 97.1 \\
\hline Min & 1.01 & 6.4 & 4.1 & -0.7 & 0.9 & 5.1 & -5.5 & 4.7 \\
\hline Std. Dev. & 315.4 & 19.3 & 17.7 & 0.6 & 3.2 & 1.9 & 0.6 & 15.5 \\
\hline \multicolumn{9}{|c|}{ Small European banks } \\
\hline Mean & 0.4 & 67.9 & 69.1 & 0.8 & 11.5 & 14.6 & 1.3 & 67.6 \\
\hline Median & 0.4 & 67.8 & 70.3 & 0.6 & 11.9 & 13.7 & 1.2 & 70.4 \\
\hline Max & 1.0 & 93.0 & 89.9 & 4.4 & 23.1 & 30.2 & 4.1 & 98.4 \\
\hline Min & 0.0 & 6.3 & 26.5 & -1.2 & 4.2 & 9.2 & -4.4 & 9.5 \\
\hline Std. Dev. & 0.3 & 16.0 & 10.8 & 0.8 & 4.0 & 3.6 & 0.9 & 14.4 \\
\hline $\begin{array}{l}\text { Test statistic \& } \\
\% \text { level }\end{array}$ & $\begin{array}{c}-7.52 * * * \\
(0.00)\end{array}$ & $\begin{array}{c}3.74 * * * \\
(0.00)\end{array}$ & $\begin{array}{c}19.07 * * * \\
(0.00)\end{array}$ & $\begin{array}{c}5.99 * * * \\
(0.00)\end{array}$ & $\begin{array}{c}20.87 * * * \\
(0.00)\end{array}$ & $\begin{array}{c}17.33 * * * \\
(0.00)\end{array}$ & $\begin{array}{c}11.28 * * * \\
(0.00)\end{array}$ & $\begin{array}{c}10.71 * * * \\
(0.00)\end{array}$ \\
\hline
\end{tabular}

Source: Bloomberg (2000-2006). All variables are expressed in percentage, except Total assets. Total assets in US\$ billion; Total loans / total assets: (commercial loans + consumer loans + other loans) / total assets; Total deposits / total assets: (demand deposits + saving deposits + time deposits + other time deposits) / total assets; Loan loss provisions / total loans: loan loss provisions / (commercial loans + consumer loans + other loans); Tier 1 capital / total assets: Tier 1 capital / total assets; Tier 1 and 2 capital / RWA: (Tier 1 capital + Tier 2 capital) / total risk weighted assets; ROA: net income / total assets; Total interest income / total income: (interest income from loans + resale agreements + interbank investments + other interest income or losses) / total income. We consider a bank large if its total assets exceed US\$1 billion. T-statistics test for null hypothesis of identical means for large and small European (respectively, U.S. banks). *, ***** indicate statistical significance at the $10 \%, 5 \%$ and $1 \%$ level, for bilateral test. 
Table 3. Balance sheets weighting used to calculate the liquidity creation indicator

\begin{tabular}{|l|c|c|}
\hline \multicolumn{1}{|c|}{ Assets } & Liquidity level & Weights \\
\hline \hline Cash and near cash items & Liquid & -0.5 \\
Interbank assets & Semiliquid & 0 \\
Short-term marketable assets & Liquid & -0.5 \\
Commercial loans & Illiquid & 0.5 \\
Consumer loans & Semiliquid & 0 \\
Other loans & Semiliquid & 0 \\
Long-term marketable assets & Semiliquid & 0 \\
Fixed assets & Illiquid & 0.5 \\
Other assets & Illiquid & 0.5 \\
Custumer acceptances & Semiliquid & 0 \\
\hline \hline & & \\
\hline \hline Demand deposits & Liquid & 0.5 \\
Saving deposits & Liquid & 0.5 \\
Time deposits & Semiliquid & 0 \\
Other term deposits & Semiliquid & 0 \\
Short-term borrowings & Liquid & 0.5 \\
Other short-term liabilities & Liquid & 0.5 \\
Long-term borrowings & Semiliquid & 0 \\
Other long-term liabilities & Semiliquid & 0 \\
Subordinated debentures & Illiquid & -0.5 \\
Prefered equity & Illiquid & -0.5 \\
Minority interests & Illiquid & -0.5 \\
Shareholder common capital & Illiquid & -0.5 \\
Retained earnings & Illiquid & -0.5 \\
\hline
\end{tabular}


Table 4. Balance sheets weighting used to calculate the inverse of the net stable funding ratio

\begin{tabular}{|c|c|c|}
\hline \multicolumn{3}{|c|}{ Required amount of stable funding } \\
\hline Assets & "Corresponding definition of BIS & Weights \\
\hline Cash and near cash items & Cash & 0 \\
\hline Interbank assets & $\begin{array}{l}\text { Nonrenewable loans to financials } \\
\text { with remaining maturity }<1 \mathrm{yr}\end{array}$ & 0 \\
\hline $\begin{array}{l}\text { Marketable securities and other } \\
\text { short-term investments }\end{array}$ & $\begin{array}{l}\text { Short-term unsecured actively traded } \\
\text { instruments (with remaining maturity } \\
<1 \text { yr) }\end{array}$ & 0 \\
\hline Commercial loans & All other assets & 1 \\
\hline Consumer loans & $\begin{array}{l}\text { Loans to retail clients (with } \\
\text { remaining maturity }<1 \text { yr) }\end{array}$ & 0.85 \\
\hline Other loans & All other assets & 1 \\
\hline Long-term investments & $\begin{array}{l}\text { Unemcumbered listed equity or } \\
\text { nonfinancial senior unsecured } \\
\text { corporate bonds rated at least A- } \\
\text { (with remaining maturity > } 1 \text { yr) }\end{array}$ & 0.5 \\
\hline Fixed assets & All other assets & 1 \\
\hline Other assets & All other assets & 1 \\
\hline Customer acceptances & $\begin{array}{l}\text { Unemcumbered listed equity or } \\
\text { nonfinancial senior unsecured } \\
\text { corporate bonds rated at least A- } \\
\text { (with remaining maturity > } 1 \text { yr) }\end{array}$ & 0.5 \\
\hline \multicolumn{3}{|c|}{ Available amount of stable funding } \\
\hline Liabilities & Corresponding definition of BIS & Weights \\
\hline $\begin{array}{l}\text { Demand deposits } \\
\text { Saving deposits }\end{array}$ & $\begin{array}{l}\text { Deposits of retail and small business } \\
\text { customers (nonmaturity or residual } \\
\text { maturity }<1 \text { yr) }\end{array}$ & $\begin{array}{l}0.7 \\
0.7\end{array}$ \\
\hline Time deposits & $\begin{array}{l}\text { Other liabilities with an effective } \\
\text { maturity }>1 \mathrm{yr}\end{array}$ & 1 \\
\hline Other term deposits & $\begin{array}{l}\text { Other liabilities with an effective } \\
\text { maturity }>1 \mathrm{yr}\end{array}$ & 1 \\
\hline Short-term borrowings & $\begin{array}{l}\text { All other liabilities or equity not } \\
\text { included above }\end{array}$ & 0 \\
\hline Other short-term liabilities & $\begin{array}{l}\text { All other liabilities or equity not } \\
\text { included above }\end{array}$ & 0 \\
\hline Long-term borrowings & $\begin{array}{l}\text { Other liabilities with an effective } \\
\text { maturity }>1 \text { yr }\end{array}$ & 1 \\
\hline Other long-term liabilities & $\begin{array}{l}\text { Other liabilities with an effective } \\
\text { maturity }>1 \text { yr }\end{array}$ & 1 \\
\hline Subordinated debentures & Tier 1 and 2 capital instruments, other & 1 \\
\hline Prefered equity & preferred shares and capital & 1 \\
\hline Minority interests & instruments in excess of Tier 2 & 1 \\
\hline Shareholder common capital & allowable amount having an effective & 1 \\
\hline Retained earnings & |maturity > 1 yr & 1 \\
\hline
\end{tabular}

Source: BIS (2009). The inverse of the net stable funding ratio $(I N S F R)$ is the ratio of the required amount of stable funding to the available amount of stable funding. It is based on the net stable funding ratio as defined in the Basel III accords. For further details about the weighting of bank balance sheet items to compute this ratio, see appendix A. 
Table 5. Descriptive statistics of explanatory variables for U.S. and European listed commercial banks, on average from 2000 to 2006

\begin{tabular}{|l|c|c|c|c|c|c|}
\hline \multicolumn{1}{|c|}{ Variables } & Mean & Median & Max & Min & Std Dev & Obs \\
\hline LC & 31.1 & 31.4 & 72.9 & -25.3 & 12.7 & 4926 \\
I_NSFR & 90.2 & 89.3 & 312.4 & 20.5 & 21.2 & 4926 \\
ROE & 11.7 & 12.1 & 47.9 & -88.1 & 7.6 & 4943 \\
LLP_TLO & 0.4 & 0.3 & 6.7 & -1.2 & 0.5 & 4873 \\
MKT_DISC & 0.7 & 0.0 & 18.5 & 0.0 & 1.4 & 4926 \\
DIV_PYRT & 31.1 & 31.7 & 100.0 & 0.0 & 22.4 & 4770 \\
MKT_BK_VAL & 1.8 & 1.7 & 7.7 & 0.0 & 0.8 & 4776 \\
LN_TA & 7.6 & 7.0 & 14.6 & 2.8 & 2.1 & 4926 \\
GDP_GWT & 2.6 & 2.7 & 9.5 & -1.6 & 1.1 & 5467 \\
CAP_REG & 5.8 & 6.0 & 8.0 & 2.0 & 0.9 & 5467 \\
T12_RWA & 13.5 & 12.7 & 36.0 & 5.1 & 3.4 & 4637 \\
T1_RWA & 11.8 & 11.1 & 35.2 & 3.3 & 3.7 & 4637 \\
MKT_POW & 1.7 & 0.0 & 74.5 & 0.0 & 6.3 & 4926 \\
CB & 3.1 & 2.3 & 15.3 & 0.3 & 1.9 & 5467 \\
IBK1M_CB & 0.1 & 0.1 & 3.5 & -0.4 & 0.2 & 5467 \\
\hline
\end{tabular}

Source: Bloomberg (2000-2006), World Bank's 2007 Regulation and Supervisory Database. All variables are expressed in percentage, except $L N_{-} T A, M K T_{-} B K_{-} V A L$ and $C A P_{-} R E G$. $L C$ : liquidity creation / total assets; $I_{-} N S F R$ : required amount of stable funding / available amount of stable funding; $R O E$ : net income / total equity; LLP TLO loan loss provisions / total loans; $M K T \_D I S C$ : subordinated debt / total debt; DIV_PYRT: common dividend / (net income - minority interests preferred dividends); $M K T \_B K \_V A L$ : market value of assets/ book value of assets; $L N \_T A$ : natural logarithm of total assets; GDP_GWT: annual growth rate of real GDP; $C A P_{2} R E G$ : index of regulatory oversight of bank capital; T12_RWA: Tier 1 and 2 capital / total risk weighted assets; $T 1 \_R W A$ : Tier 1 capital / total risk weighted assets; $M K T+P O W$ : total assets of bank $i$ in country $j$ / total assets of the banking system in country $j ; C B$ : central bank policy rate; $I B K \overline{1} M_{-} C B$ : spread of 1 month interbank rate and central bank policy rate. 
Table 6. Liquidity and regulatory capital ratios

\begin{tabular}{|c|c|c|c|c|}
\hline & \multicolumn{2}{|c|}{$\begin{array}{c}\text { Tier } 1 \& 2 \\
\text { regulatory capital ratio }\end{array}$} & \multicolumn{2}{|c|}{$\begin{array}{c}\text { Tier } 1 \\
\text { regulatory capital ratio }\end{array}$} \\
\hline & $1 . \mathrm{a}$ & $1 . \mathrm{b}$ & 1. $a^{\prime}$ & 1. $b^{\prime}$ \\
\hline \multicolumn{5}{|c|}{ Regulatory capital equation } \\
\hline $\mathrm{LC}$ & $\begin{array}{c}-0.03 * * \\
(-2.25)\end{array}$ & - & $\begin{array}{l}-0.003 \\
(-0.24)\end{array}$ & - \\
\hline I_NSFR & - & $\begin{array}{c}-0.02 * * \\
(-2.07)\end{array}$ & - & $\begin{array}{l}-0.003 \\
(-0.37)\end{array}$ \\
\hline ROE & $\begin{array}{c}0.01 \\
(1.20)\end{array}$ & $\begin{array}{c}0.01 \\
(1.35)\end{array}$ & $\begin{array}{c}0.02 * * \\
(1.99)\end{array}$ & $\begin{array}{l}0.02 * \\
(1.77)\end{array}$ \\
\hline LLP_TLO & $\begin{array}{c}0.37 * * * \\
(4.04)\end{array}$ & $\begin{array}{c}0.42 * * * \\
(4.34)\end{array}$ & $\begin{array}{l}0.43 * * * \\
(4.24)\end{array}$ & $\begin{array}{c}0.45 * * * \\
(4.40)\end{array}$ \\
\hline MKT_DISC & - & - & $\begin{array}{c}0.04 \\
(1.53)\end{array}$ & $\begin{array}{l}0.05 * \\
(1.69)\end{array}$ \\
\hline DIV_PYRT & $\begin{array}{c}-0.01 * * * \\
(-2.45)\end{array}$ & $\begin{array}{c}-0.01 * * * \\
(-2.84)\end{array}$ & $\begin{array}{c}-0.01 * * * \\
(-3.86)\end{array}$ & $\begin{array}{c}-0.01 * * * \\
(-3.98)\end{array}$ \\
\hline MKT_BK_VAL & $\begin{array}{l}-0.001 \\
(-0.78)\end{array}$ & $\begin{array}{l}-0.001 \\
(-1.13)\end{array}$ & $\begin{array}{l}0.005 \\
(0.68)\end{array}$ & $\begin{array}{l}0.004 \\
(0.57)\end{array}$ \\
\hline LN_TA & $\begin{array}{l}0.005 * * * \\
\quad(2.94)\end{array}$ & $\begin{array}{c}0.003 * * \\
(1.94)\end{array}$ & $\begin{array}{l}0.002 \\
(1.29)\end{array}$ & $\begin{array}{l}0.002 \\
(1.20)\end{array}$ \\
\hline GDP_GWT & $\begin{array}{c}-0.02 \\
(-0.48)\end{array}$ & $\begin{array}{l}-0.03 \\
(-0.67)\end{array}$ & $\begin{array}{l}-0.04 \\
(-0.87)\end{array}$ & $\begin{array}{l}-0.02 \\
(-0.55)\end{array}$ \\
\hline CAP_REG & $\begin{array}{l}-0.01 \\
(-0.15)\end{array}$ & $\begin{array}{l}-0.01 \\
(-0.19)\end{array}$ & $\begin{array}{c}0.01 \\
(0.16)\end{array}$ & $\begin{array}{l}0.003 \\
(0.06)\end{array}$ \\
\hline \multicolumn{5}{|c|}{ Liquidity equation } \\
\hline K_RWA & $\begin{array}{c}-1.90 * * * \\
(-2.78)\end{array}$ & $\begin{array}{c}-3.45 * * * \\
(-3.16)\end{array}$ & $\begin{array}{l}-0.91 * \\
(-1.73)\end{array}$ & $\begin{array}{c}-2.46 * * * \\
(-2.85)\end{array}$ \\
\hline MKT_POW & $\begin{array}{c}-0.08 \\
(-0.39)\end{array}$ & $\begin{array}{c}-0.18 \\
(-0.36)\end{array}$ & $\begin{array}{c}-0.25 \\
(-1.15)\end{array}$ & $\begin{array}{c}-0.61 \\
(-1.12)\end{array}$ \\
\hline GDP_GWT & $\begin{array}{c}0.69 * * * \\
(3.31)\end{array}$ & $\begin{array}{c}0.15 \\
(0.33)\end{array}$ & $\begin{array}{c}0.81 * * * \\
(4.14)\end{array}$ & $\begin{array}{c}0.35 \\
(0.82)\end{array}$ \\
\hline $\mathrm{CB}$ & $\begin{array}{c}-0.63 \\
(-0.41)\end{array}$ & $\begin{array}{c}1.04 \\
(0.38)\end{array}$ & $\begin{array}{c}-0.58 \\
(-0.33)\end{array}$ & $\begin{array}{c}1.60 \\
(0.55)\end{array}$ \\
\hline IBK1M_CB & $\begin{array}{c}1.86 * * * \\
(14.38)\end{array}$ & $\begin{array}{c}2.98 * * * \\
(11.40)\end{array}$ & $\begin{array}{c}2.02 * * * \\
(19.23)\end{array}$ & $\begin{array}{c}3.13 * * * \\
(13.30)\end{array}$ \\
\hline Total Obs. & 3644 & 3644 & 3644 & 3644 \\
\hline
\end{tabular}

This table shows the results of estimating system (1) using GMM for an unbalanced panel of U.S. and European publicly traded commercial banks over the 2000-2006 period. The $K \_R W A$ variable is either the Tier 1 and 2 capital to total risk weighted assets (T12_RWA in systems (1.a) and (1.b)) or the Tier 1 capital to total risk weighted assets (T1_RWA in systems $\left(1 . a^{\prime}\right)$ and $\left.\left(1 . b^{\prime}\right)\right)$. The liquidity variable is either the liquidity creation indicator $\left(L C\right.$ in systems $(1 . a)$ and $\left.\left(1 . a^{\prime}\right)\right)$ or the inverse of the net stable funding ratio (I_NSFR in systems (1.b) and $\left.\left(1 . b^{\prime}\right)\right)$. A higher value of each liquidity proxy indicates higher bank illiquidity. See Table 5 for the definition of the explanatory variables. We include cross-section and time fixed effects in the regressions and we use the White cross-section covariance method. In both the regulatory capital and the liquidity equations, all bank-level explanatory variables which are presumably endogenous in the existing literature are replaced by their one-year lagged value. ${ }^{*}, * *$ and $* * *$ indicate statistical significance at the $10 \%, 5 \%$ and $1 \%$ levels, respectively. 
Table 7. Liquidity and regulatory capital ratios for European banks

\begin{tabular}{|c|c|c|c|c|}
\hline & \multicolumn{2}{|c|}{$\begin{array}{c}\text { Tier } 1 \& 2 \\
\text { regulatory capital ratio }\end{array}$} & \multicolumn{2}{|c|}{$\begin{array}{c}\text { Tier } 1 \\
\text { regulatory capital ratio }\end{array}$} \\
\hline & 1. a & 1.b & 1. $\mathbf{a}^{\prime}$ & 1. $\mathbf{b}^{\prime}$ \\
\hline \multicolumn{5}{|c|}{ Regulatory capital equation } \\
\hline $\mathrm{LC}$ & $\begin{array}{c}-0.15 * * * \\
(-2.69)\end{array}$ & - & $\begin{array}{c}-0.09 * * \\
(-2.04)\end{array}$ & - \\
\hline I_NSFR & - & $\begin{array}{c}-0.05 * * \\
(-2.31)\end{array}$ & - & $\begin{array}{c}-0.02 \\
(-1.19)\end{array}$ \\
\hline ROE & $\begin{array}{c}0.01 \\
(0.81)\end{array}$ & $\begin{array}{l}0.003 \\
(0.25)\end{array}$ & $\begin{array}{c}0.01 \\
(1.01)\end{array}$ & $\begin{array}{c}0.01 \\
(0.85)\end{array}$ \\
\hline LLP_TLO & $\begin{array}{c}0.18 \\
(0.83)\end{array}$ & $\begin{array}{c}0.13 \\
(0.63)\end{array}$ & $\begin{array}{c}0.26 \\
(1.35)\end{array}$ & $\begin{array}{c}0.37 * * \\
(2.17)\end{array}$ \\
\hline MKT_DISC & - & - & $\begin{array}{c}0.01 \\
(0.27)\end{array}$ & $\begin{array}{c}0.01 \\
(0.34)\end{array}$ \\
\hline DIV_PYRT & $\begin{array}{l}0.002 \\
(0.74)\end{array}$ & $\begin{array}{l}0.003 \\
(0.86)\end{array}$ & $\begin{array}{l}-0.003 \\
(-1.02)\end{array}$ & $\begin{array}{l}-0.003 \\
(-1.33)\end{array}$ \\
\hline MKT_BK_VAL & $\begin{array}{l}0.001 \\
(0.24)\end{array}$ & $\begin{array}{l}0.001 \\
(0.59)\end{array}$ & $\begin{array}{l}-0.002 \\
(-1.46)\end{array}$ & $\begin{array}{l}-0.003 \\
(-1.41)\end{array}$ \\
\hline LN_TA & $\begin{array}{l}-0.01 \\
(-1.29)\end{array}$ & $\begin{array}{c}-0.01 \\
(-1.25)\end{array}$ & $\begin{array}{l}-0.002 \\
(-0.45)\end{array}$ & $\begin{array}{l}-0.001 \\
(-0.20)\end{array}$ \\
\hline GDP_GWT & $\begin{array}{l}0.21 * * * \\
(2.70)\end{array}$ & $\begin{array}{c}0.10 \\
(1.47)\end{array}$ & $\begin{array}{c}0.24 * * * \\
(3.58)\end{array}$ & $\begin{array}{c}0.17 * * * \\
(2.91)\end{array}$ \\
\hline CAP_REG & $\begin{array}{l}0.002 \\
(0.13)\end{array}$ & $\begin{array}{l}0.000 \\
(0.02)\end{array}$ & $\begin{array}{l}-0.001 \\
(-0.08)\end{array}$ & $\begin{array}{l}-0.004 \\
(-0.26)\end{array}$ \\
\hline \multicolumn{5}{|c|}{ Liquidity equation } \\
\hline K_RWA & $\begin{array}{l}0.21 \\
(0.16)\end{array}$ & $\begin{array}{l}-3.13 \\
(-1.10)\end{array}$ & $\begin{array}{c}-2.70 * * * \\
(-2.87)\end{array}$ & $\begin{array}{c}-9.35 * * * \\
(-4.32)\end{array}$ \\
\hline MKT_POW & $\begin{array}{l}-0.24 * \\
(-1.64)\end{array}$ & $\begin{array}{l}-0.69 * \\
(-1.78)\end{array}$ & $\begin{array}{c}-0.14 \\
(-0.82)\end{array}$ & $\begin{array}{l}-0.77 * \\
(-1.82)\end{array}$ \\
\hline GDP_GWT & $\begin{array}{c}1.21 * * * \\
(4.24)\end{array}$ & $\begin{array}{c}1.48 * * \\
(2.20)\end{array}$ & $\begin{array}{c}1.45 * * * \\
(4.79)\end{array}$ & $\begin{array}{c}2.28 * * * \\
(3.09)\end{array}$ \\
\hline $\mathrm{CB}$ & $\begin{array}{c}-0.75 \\
(-0.44)\end{array}$ & $\begin{array}{c}3.77 \\
(1.00)\end{array}$ & $\begin{array}{c}0.57 \\
(0.43)\end{array}$ & $\begin{array}{l}4.37 * \\
(1.72)\end{array}$ \\
\hline IBK1M_CB & $\begin{array}{c}1.60 * * * \\
(4.60)\end{array}$ & $\begin{array}{c}3.39 * * * \\
(4.25)\end{array}$ & $\begin{array}{c}1.26 * * * \\
(4.04)\end{array}$ & $\begin{array}{c}3.02 * * * \\
(4.19)\end{array}$ \\
\hline Total Obs. & 858 & 858 & 858 & 858 \\
\hline
\end{tabular}

This table shows the results of estimating system (1) using GMM for an unbalanced panel of European publicly traded commercial banks over the 2000-2006 period. The $K_{-} R W A$ variable is either the Tier 1 and 2 capital to total risk weighted assets (T12 RWA in systems (1.a) and (1.b)) or the Tier 1 capital to total risk weighted assets (T1 RWA in systems $\left(1 . \mathrm{a}^{\prime}\right)$ and $\left.\left(1 . b^{\prime}\right)\right)$. The liquidity variable is either the liquidity creation indicator $\left(L C\right.$ in systems $(1 . a)$ and $\left.\left(1 . \mathrm{a}^{\prime}\right)\right)$ or the inverse of the net stable funding ratio $\left(I_{-} N S F R\right.$ in systems $(1 . b)$ and $\left.\left(1 . b^{\prime}\right)\right)$. A higher value of each liquidity proxy indicates higher bank illiquidity. See Table 5 for the definition of the explanatory variables. We include cross-section and time fixed effects in the regressions and we use the White cross-section covariance method. In both the regulatory capital and the liquidity equations, all bank-level explanatory variables which are presumably endogenous in the existing literature are replaced by their one-year lagged value. *,* and *** indicate statistical significance at the $10 \%, 5 \%$ and $1 \%$ levels, respectively. 
Table 8. Liquidity and regulatory capital ratios for U.S. banks

\begin{tabular}{|c|c|c|c|c|c|c|}
\hline & \multicolumn{3}{|c|}{$\begin{array}{c}\text { Tier } 1 \& 2 \\
\text { regulatory capital ratio }\end{array}$} & \multicolumn{3}{|c|}{$\begin{array}{c}\text { Tier } 1 \\
\text { regulatory capital ratio }\end{array}$} \\
\hline & $1 . \mathrm{a}$ & $1 . \mathrm{b}$ & $1 . \mathrm{c}$ & $1 . a^{\prime}$ & $\overline{1 . b^{\prime}}$ & $1 . c^{\prime}$ \\
\hline \multicolumn{7}{|c|}{ Regulatory capital equation } \\
\hline $\mathrm{LC}$ & $\begin{array}{c}-0.07 * * * \\
(-3.75)\end{array}$ & - & - & $\begin{array}{c}-0.06 * * * \\
(-3.23)\end{array}$ & - & - \\
\hline I_NSFR & - & $\begin{array}{c}-0.06 * * * \\
(-3.92)\end{array}$ & - & - & $\begin{array}{c}-0.06 * * * \\
(-3.49)\end{array}$ & - \\
\hline CFR & - & - & $\begin{array}{c}-0.05 * * * \\
(-3.53)\end{array}$ & - & - & $\begin{array}{c}-0.06 * * * \\
(-3.85)\end{array}$ \\
\hline ROE & $\begin{array}{l}0.02 * \\
(1.71)\end{array}$ & $\begin{array}{c}0.01 \\
(1.24)\end{array}$ & $\begin{array}{c}0.01 \\
(1.11)\end{array}$ & $\begin{array}{l}0.02 * \\
(1.87)\end{array}$ & $\begin{array}{c}0.02 \\
(1.40)\end{array}$ & $\begin{array}{c}0.02 \\
(1.28)\end{array}$ \\
\hline LLP_TLO & $\begin{array}{c}0.35 * * * \\
(3.13)\end{array}$ & $\begin{array}{c}0.25 * * \\
(2.17)\end{array}$ & $\begin{array}{c}0.33 * * * \\
(2.80)\end{array}$ & $\begin{array}{c}0.29 * * * \\
(2.49)\end{array}$ & $\begin{array}{c}0.18 \\
(1.52)\end{array}$ & $\begin{array}{c}0.28 * * \\
(2.29)\end{array}$ \\
\hline MKT_DISC & - & - & - & $\begin{array}{c}0.02 \\
(0.48)\end{array}$ & $\begin{array}{c}0.04 \\
(0.83)\end{array}$ & $\begin{array}{c}0.06 \\
(1.35)\end{array}$ \\
\hline DIV_PYRT & $\begin{array}{c}-0.02 * * * \\
(-4.60)\end{array}$ & $\begin{array}{c}-0.02 * * * \\
(-4.65)\end{array}$ & $\begin{array}{c}-0.02 * * * \\
(-4.32)\end{array}$ & $\begin{array}{c}-0.02 * * * \\
(-4.47)\end{array}$ & $\begin{array}{c}-0.02 * * * \\
(-4.45)\end{array}$ & $\begin{array}{c}-0.02 * * * \\
(-4.03)\end{array}$ \\
\hline MKT_BK_VAL & $\begin{array}{l}0.001 \\
(0.85)\end{array}$ & $\begin{array}{l}0.001 \\
(1.32)\end{array}$ & $\begin{array}{l}0.001 \\
(0.65)\end{array}$ & $\begin{array}{c}0.002 * * \\
(2.23)\end{array}$ & $\begin{array}{c}0.002 * * * \\
\quad(2.70)\end{array}$ & $\begin{array}{c}0.001 * \\
(1.75)\end{array}$ \\
\hline LN_TA & $\begin{array}{c}0.004 * \\
(1.76)\end{array}$ & $\begin{array}{c}0.01 * * * \\
(2.69)\end{array}$ & $\begin{array}{c}0.01 * * * \\
(3.14)\end{array}$ & $\begin{array}{c}0.004 * \\
(1.87)\end{array}$ & $\begin{array}{c}0.01 * * * \\
(2.82)\end{array}$ & $\begin{array}{c}0.01 * * * \\
(3.16)\end{array}$ \\
\hline GDP_GWT & $\begin{array}{c}0.03 \\
(0.12) \\
\end{array}$ & $\begin{array}{c}-0.01 \\
(-0.03) \\
\end{array}$ & $\begin{array}{c}-0.05 \\
(-0.22) \\
\end{array}$ & $\begin{array}{c}0.07 \\
(0.31)\end{array}$ & $\begin{array}{c}0.05 \\
(0.25)\end{array}$ & $\begin{array}{c}0.10 \\
(0.46)\end{array}$ \\
\hline \multicolumn{7}{|c|}{ Liquidity equation } \\
\hline K_RWA & $\begin{array}{c}0.54 \\
(1.02)\end{array}$ & $\begin{array}{c}1.04 \\
(1.45)\end{array}$ & $\begin{array}{l}1.49 * \\
(1.88)\end{array}$ & $\begin{array}{c}0.72 \\
(1.45)\end{array}$ & $\begin{array}{r}1.25 * * \\
(1.88)\end{array}$ & $\begin{array}{c}1.35 * * \\
(1.92)\end{array}$ \\
\hline MKT_POW & $\begin{array}{l}-1.53 * \\
(-1.73)\end{array}$ & $\begin{array}{c}-1.19 \\
(-0.88)\end{array}$ & $\begin{array}{l}-1.63 \\
(-0.76)\end{array}$ & $\begin{array}{l}-1.72 * \\
(-1.83)\end{array}$ & $\begin{array}{l}-1.66 \\
(-1.21)\end{array}$ & $\begin{array}{l}-2.78 \\
(-1.43)\end{array}$ \\
\hline GDP_GWT & $\begin{array}{c}2.15 * * * \\
(2.64)\end{array}$ & $\begin{array}{c}1.67 \\
(1.50)\end{array}$ & $\begin{array}{r}2.46 * * \\
(2.30)\end{array}$ & $\begin{array}{c}2.12 * * * \\
(2.54)\end{array}$ & $\begin{array}{c}1.55 \\
(1.37)\end{array}$ & $\begin{array}{c}2.34 * * \\
(2.23)\end{array}$ \\
\hline $\mathrm{CB}$ & $\begin{array}{l}-21.56 \\
(-1.16)\end{array}$ & $\begin{array}{c}-8.02 \\
(-0.32)\end{array}$ & $\begin{array}{l}-28.80 \\
(-1.00)\end{array}$ & $\begin{array}{l}-22.03 \\
(-1.18)\end{array}$ & $\begin{array}{c}-8.48 \\
(-0.34)\end{array}$ & $\begin{array}{l}-24.52 \\
(-0.86)\end{array}$ \\
\hline IBK1M_CB & $\begin{array}{l}0.71 * \\
(1.87) \\
\end{array}$ & $\begin{array}{c}1.38 * * * \\
(2.66)\end{array}$ & $\begin{array}{c}1.11 * * \\
(2.14)\end{array}$ & $\begin{array}{l}0.70 * \\
(1.84)\end{array}$ & $\begin{array}{c}1.37 * * * \\
(2.64)\end{array}$ & $\begin{array}{c}1.15 * * \\
(2.26) \\
\end{array}$ \\
\hline Total Obs. & 2786 & 2786 & 2781 & 2786 & 2786 & 2781 \\
\hline
\end{tabular}

This table shows the results of estimating system (1) using GMM for an unbalanced panel of U.S. publicly traded commercial banks over the 2000-2006 period. The $K_{-} R W A$ variable is either the Tier 1 and 2 capital to total risk weighted assets $\left(T 12 \_R W A\right.$ in systems (1.a), (1.b) and (1.c)) or the Tier 1 capital to total risk weighted assets $\left(T 1 \_R W A\right.$ in systems $\left(1 . \mathrm{a}^{\prime}\right)$, $\left(1 . b^{\prime}\right)$ and $\left.\left(1 . c^{\prime}\right)\right)$. The liquidity variable is either the liquidity creation indicator $\left(L C\right.$ in systems $(1 . a)$ and $\left.\left(1 . a^{\prime}\right)\right)$, the inverse of the net stable funding ratio $\left(I-N S F R\right.$ in systems $(1 . b)$ and $\left.\left(1 . b^{\prime}\right)\right)$ or the core funding ratio $\left(C F R\right.$ in systems $(1 . c)$ and $\left.\left(1 . c^{\prime}\right)\right)$. A higher value of each liquidity proxy indicates higher bank illiquidity. See Table 5 for the definition of the explanatory variables. We include cross-section and time fixed effects in the regressions and we use the White cross-section covariance method. In both the regulatory capital and the liquidity equations, all bank-level explanatory variables which are presumably endogenous in the existing literature are replaced by their one-year lagged value. $*$, ** and $* * *$ indicate statistical significance at the $10 \%, 5 \%$ and $1 \%$ levels, respectively. 
Table 9. Liquidity and regulatory capital ratios separately for European and U.S. banks according to their size

\begin{tabular}{|c|c|c|c|c|c|c|c|c|c|c|c|c|}
\hline & \multicolumn{6}{|c|}{ Tier $1 \& 2$ regulatory capital ratio } & \multicolumn{6}{|c|}{ Tier 1 regulatory capital ratio } \\
\hline & \multicolumn{3}{|c|}{ Large banks } & \multicolumn{3}{|c|}{ Small banks } & \multicolumn{3}{|c|}{ Large banks } & \multicolumn{3}{|c|}{ Small banks } \\
\hline & 1. a & $1 . \mathrm{b}$ & 1.c & $1 . \mathbf{a}$ & 1.b & 1. c & 1. $\mathbf{a}^{\prime}$ & $1 . \mathrm{b}^{\prime}$ & 1. $\mathrm{c}^{\prime}$ & 1. $\mathbf{a}^{\prime}$ & $1 . \mathbf{b}^{\prime}$ & 1. $\mathbf{c}^{\prime}$ \\
\hline \multicolumn{13}{|c|}{ Panel A: European banks } \\
\hline LC & $\begin{array}{c}0.01 \\
(0.27)\end{array}$ & - & - & $\begin{array}{c}-0.05 \\
(-0.49)\end{array}$ & - & - & $\begin{array}{c}0.01 \\
(0.25)\end{array}$ & - & - & $\begin{array}{l}0.001 \\
(0.03)\end{array}$ & - & - \\
\hline I_NSFR & - & $\begin{array}{c}-0.02 \\
(-1.03)\end{array}$ & - & - & $\begin{array}{l}-0.004 \\
(-0.06)\end{array}$ & - & - & $\begin{array}{c}-0.02 \\
(-1.08)\end{array}$ & - & - & $\begin{array}{c}0.01 \\
(0.39)\end{array}$ & - \\
\hline Total Obs. & 669 & 669 & - & 189 & 189 & - & 669 & 669 & - & 189 & 189 & - \\
\hline \multicolumn{13}{|c|}{ Panel B: U.S. banks } \\
\hline LC & $\begin{array}{c}-0.09 * * * \\
(-4.98)\end{array}$ & - & - & $\begin{array}{c}-0.05 \\
(-0.96)\end{array}$ & - & - & $\begin{array}{c}-0.05 * * * \\
(-2.78)\end{array}$ & - & - & $\begin{array}{c}-0.04 \\
(-0.83)\end{array}$ & - & - \\
\hline I_NSFR & - & $\begin{array}{c}-0.07 * * * \\
(-5.50)\end{array}$ & - & - & $\begin{array}{c}0.01 \\
(0.13)\end{array}$ & - & - & $\begin{array}{c}-0.04 * * * \\
(-2.67)\end{array}$ & - & - & $\begin{array}{c}0.01 \\
(0.15)\end{array}$ & - \\
\hline CFR & - & - & $\begin{array}{c}-0.06 * * * \\
(-4.96)\end{array}$ & - & - & $\begin{array}{c}0.08 * * \\
(2.08)\end{array}$ & - & - & $\begin{array}{c}-0.04 * * * \\
(-2.91)\end{array}$ & - & - & $\begin{array}{l}0.07 * \\
(1.86)\end{array}$ \\
\hline Total Obs. & 1189 & 1189 & 1184 & 1597 & 1597 & 1597 & 1189 & 1189 & 1184 & 1597 & 1597 & 1597 \\
\hline
\end{tabular}

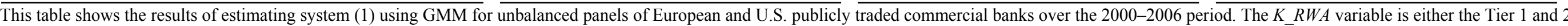

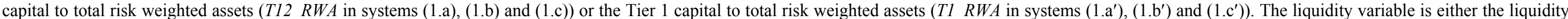

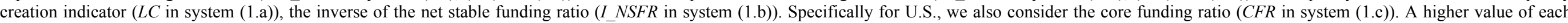

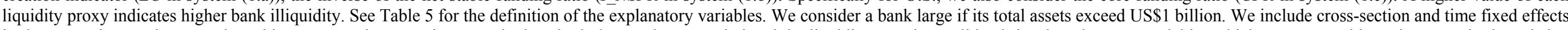

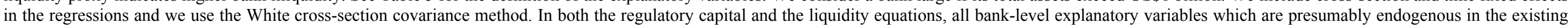
literature are replaced by their one-year lagged value. ${ }^{*}, * *$ and $* * *$ indicate statistical significance at the $10 \%, 5 \%$ and $1 \%$ levels, respectively.

\section{Table 10. Liquidity and regulatory capital ratios separately for European and U.S. banks considering very large versus other large banks}

\begin{tabular}{|c|c|c|c|c|c|c|c|c|c|c|c|c|}
\hline & \multicolumn{6}{|c|}{ Tier 1 \& 2 regulatory capital ratio } & \multicolumn{6}{|c|}{ Tier 1 regulatory capital ratio } \\
\hline & \multicolumn{3}{|c|}{ Very Large banks } & \multicolumn{3}{|c|}{ Other Large banks } & \multicolumn{3}{|c|}{ Very Large banks } & \multicolumn{3}{|c|}{ Other Large banks } \\
\hline & $1 . \mathbf{a}$ & 1. b & $1 . \mathrm{c}$ & 1. a & 1.b & 1.c & 1. a' & $1 . \mathrm{b}^{\prime}$ & 1. $\mathbf{c}^{\prime}$ & 1. $\mathbf{a}^{\prime}$ & $1 . \mathrm{b}^{\prime}$ & 1. $\mathrm{e}^{\prime}$ \\
\hline \multicolumn{13}{|c|}{ Panel A: European banks } \\
\hline LC & $\begin{array}{c}-0.02 \\
(-1.09)\end{array}$ & - & - & $\begin{array}{l}-0.08 * \\
(-1.64)\end{array}$ & - & - & $\begin{array}{c}-0.02 \\
(-1.09)\end{array}$ & - & - & $\begin{array}{l}-0.03 * \\
(-1.84)\end{array}$ & - & - \\
\hline I_NSFR & - & $\begin{array}{c}-0.01 \\
(-1.44)\end{array}$ & - & - & $\begin{array}{c}-0.09 * * \\
(-1.92)\end{array}$ & - & - & $\begin{array}{c}-0.01 \\
(-1.29)\end{array}$ & - & - & $\begin{array}{l}-0.03 * \\
(-1.64)\end{array}$ & - \\
\hline Total Obs. & 265 & 265 & - & 404 & 404 & - & 265 & 265 & - & 404 & 404 & - \\
\hline \multicolumn{13}{|c|}{ Panel B: U.S. banks } \\
\hline $\mathrm{LC}$ & $\begin{array}{c}0.05 \\
(0.25)\end{array}$ & - & - & $\begin{array}{c}-0.10 * * * \\
(-5.74)\end{array}$ & - & - & $\begin{array}{c}-0.10 \\
(-0.37)\end{array}$ & - & - & $\begin{array}{c}-0.06 * * * \\
(-3.36)\end{array}$ & - & - \\
\hline I_NSFR & - & $\begin{array}{c}0.01 \\
(0.04)\end{array}$ & - & - & $\begin{array}{c}-0.08 * * * \\
(-5.97)\end{array}$ & - & - & $\begin{array}{c}0.20 \\
(0.57)\end{array}$ & - & - & $\begin{array}{c}-0.05 * * * \\
(-3.29)\end{array}$ & - \\
\hline CFR & - & - & $\begin{array}{c}0.03 \\
(0.93)\end{array}$ & - & - & $\begin{array}{c}-0.08 * * * \\
(-5.65)\end{array}$ & - & - & $\begin{array}{c}0.08 \\
(1.12)\end{array}$ & - & - & $\begin{array}{c}-0.05 * * * \\
(-3.07)\end{array}$ \\
\hline Total Obs. & 114 & 114 & 114 & 1075 & 1075 & 1070 & 114 & 114 & 114 & 1075 & 1075 & 1070 \\
\hline
\end{tabular}

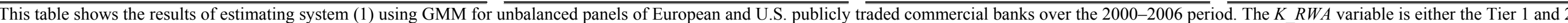

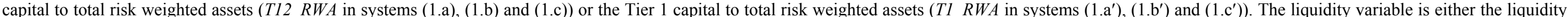

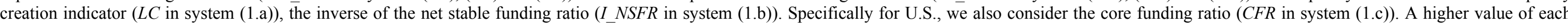

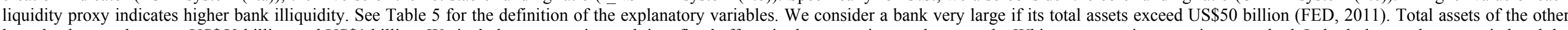

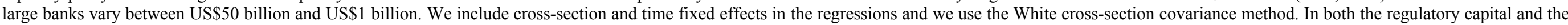

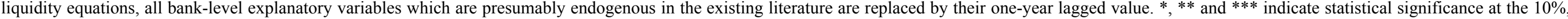
$5 \%$ and $1 \%$ levels, respectively. 


\section{APPENDIX A}

Table A.1. Summary of the balance sheets weighting used to calculate net stable funding ratio as defined in the Basel III accords

\begin{tabular}{|c|c|}
\hline Available funding source & $\begin{array}{l}\text { Availability } \\
\text { factor }\end{array}$ \\
\hline $\begin{array}{l}\text { Tier } 1 \text { and } 2 \text { Capital Instruments } \\
\text { Other preferred shares and capital instruments in excess of } \\
\text { Tier } 2 \text { allowable amount having an effective maturity of one } \\
\text { year or greater } \\
\text { Other liabilities with an effective maturity of } 1 \text { year or } \\
\text { greater }\end{array}$ & s. \\
\hline $\begin{array}{l}\text { Less stable deposits of retail and small business customers } \\
\text { (nonmaturity or residual maturity }<1 \mathrm{yr} \text { ) }\end{array}$ & 0.85 \\
\hline $\begin{array}{l}\text { Less stable deposits of retail and small business customers } \\
\text { that are not covered by effective deposit insurance, high- } \\
\text { value deposits, internet deposits and foreign currency } \\
\text { deposits (nonmaturity or residual maturity }<1 \text { yr) }\end{array}$ & 0.7 \\
\hline $\begin{array}{l}\text { Wholesale funding provided by nonfinancial corporate } \\
\text { customers (nonmaturity or residual maturity }<1 \text { yr) }\end{array}$ & 0.5 \\
\hline All other liabilities and equity not included above & 0 \\
\hline Required funding source & Required factor \\
\hline $\begin{array}{l}\text { Cash } \\
\text { Short-term unsecured actively traded instruments }(<1 \mathrm{yr}) \\
\text { Securities with exactly offsetting reverse repo } \\
\text { Securities with remaining maturity }<1 \mathrm{yr} \\
\text { Nonrenewable loans to financials with remaining maturity }< \\
1 \mathrm{yr}\end{array}$ & 0 \\
\hline $\begin{array}{l}\text { Debt issued or guaranteed by sovereigns, central banks, BIS, } \\
\text { IMF, EC, non-central government, multilateral development } \\
\text { banks }\end{array}$ & 0.05 \\
\hline $\begin{array}{l}\text { Unencumbered non-financial senior unsecured corporate } \\
\text { bonds (or covered bonds) rated at least } \mathrm{AA} \text {, maturity } \geq 1 \mathrm{yr}\end{array}$ & 0.2 \\
\hline $\begin{array}{l}\text { Unencumbered listed equity securities or nonfinancial senior } \\
\text { unsecured corporate bonds (or covered bonds) rated at least } \\
\text { A-, maturity } \geq 1 \mathrm{yr} \\
\text { Gold } \\
\text { Loans to nonfinancial corporate clients having a maturity }<1 \\
\text { yr }\end{array}$ & 0.5 \\
\hline Loans to retail clients having a maturity $<1 \mathrm{yr}$ & 0.85 \\
\hline All other assets & 1 \\
\hline
\end{tabular}

Source: BIS (2009). 


\section{APPENDIX B}

Table B.1. Correlations among the main explanatory variables in the regulatory capital equation for U.S. and European listed commercial banks from 2000 to 2006

\begin{tabular}{|c|c|c|c|c|c|c|c|c|c|c|}
\hline & LC & I_NSFR & ROA & LLP_TLO & MKT_DISC & DIV_PYRT & MKT_BK_VAL & LN_TA & GDP_GWT & CAP_REG \\
\hline $\mathrm{LC}$ & 1 & & & & & & & & & \\
\hline I_NSFR & $\begin{array}{l}0.67 \\
0.00\end{array}$ & 1 & & & & & & & & \\
\hline ROE & $\begin{array}{c}0.08 \\
0.00\end{array}$ & $\begin{array}{l}0.07 \\
0.00\end{array}$ & 1 & & & & & & & \\
\hline LLP_TLO & $\begin{array}{c}0.02 \\
0.16\end{array}$ & $\begin{array}{c}0.02 \\
0.10\end{array}$ & $\begin{array}{l}-0.20 \\
0.00\end{array}$ & 1 & & & & & & \\
\hline MKT_DISC & $\begin{array}{l}0.08 \\
0.00\end{array}$ & $\begin{array}{c}0.14 \\
0.00\end{array}$ & $\begin{array}{c}0.11 \\
0.00\end{array}$ & $\begin{array}{l}-0.03 \\
0.09\end{array}$ & 1 & & & & & \\
\hline DIV_PYRT & $\begin{array}{l}-0.20 \\
0.00\end{array}$ & $\begin{array}{l}-0.06 \\
0.00\end{array}$ & $\begin{array}{c}0.04 \\
0.01\end{array}$ & $\begin{array}{l}-0.03 \\
0.04\end{array}$ & $\begin{array}{l}-0.12 \\
0.00\end{array}$ & 1 & & & & \\
\hline MKT_BK_VAL & $\begin{array}{c}0.12 \\
0.00\end{array}$ & $\begin{array}{l}-0.06 \\
0.00\end{array}$ & $\begin{array}{r}0.48 \\
0.00\end{array}$ & $\begin{array}{l}-0.13 \\
0.00\end{array}$ & $\begin{array}{l}0.06 \\
0.00\end{array}$ & $\begin{array}{c}0.06 \\
0.00\end{array}$ & 1 & & & \\
\hline LN_TA & $\begin{array}{l}0.07 \\
0.00\end{array}$ & $\begin{array}{c}0.28 \\
0.00\end{array}$ & $\begin{array}{c}0.21 \\
0.00\end{array}$ & $\begin{array}{l}0.07 \\
0.00\end{array}$ & $\begin{array}{r}0.10 \\
0.00\end{array}$ & $\begin{array}{c}0.22 \\
0.00\end{array}$ & $\begin{array}{c}0.21 \\
0.00\end{array}$ & 1 & & \\
\hline GDP_GWT & $\begin{array}{l}0.03 \\
0.08\end{array}$ & $\begin{array}{l}-0.02 \\
0.13\end{array}$ & $\begin{array}{c}0.15 \\
0.00\end{array}$ & $\begin{array}{l}-0.18 \\
0.00\end{array}$ & $\begin{array}{c}0.02 \\
0.10\end{array}$ & $\begin{array}{l}-0.01 \\
0.32\end{array}$ & $\begin{array}{c}0.22 \\
0.00\end{array}$ & $\begin{array}{l}-0.03 \\
0.07\end{array}$ & 1 & \\
\hline CAP_REG & $\begin{array}{l}-0.02 \\
0.09\end{array}$ & $\begin{array}{r}0.00 \\
0.90\end{array}$ & $\begin{array}{l}-0.02 \\
0.26\end{array}$ & $\begin{array}{l}-0.14 \\
0.00\end{array}$ & $\begin{array}{l}-0.05 \\
0.00\end{array}$ & $\begin{array}{l}-0.04 \\
0.02\end{array}$ & $\begin{array}{l}-0.04 \\
0.00\end{array}$ & $\begin{array}{l}-0.15 \\
0.00\end{array}$ & $\begin{array}{r}0.10 \\
0.00\end{array}$ & 1 \\
\hline
\end{tabular}

All variables are expressed in percentage, except $L N T A, M K T B K V A L$ and $C A P R E G$. $L C$ : liquidity creation / total assets; I NSFR: required amount of stable funding / available amount of stable funding; ROE: net income / total equity; $L L P_{-}$TLO loan loss provisions / total loans; $M K T$ DISC: subordinated debt / total debt; DIV_PYRT: common dividend / (net income - minority interests - preferred dividends); $M K T_{-} B K_{-} V A L$ : market value of assets/ book value of assets; $L N_{-} T A$ : natural logarithm of total assets; GDP_GWT: annual growth rate of real GDP; $C A P \_R E G$ : index of regulatory oversight of bank capital. Figures in italics indicate -values of the T-statistics that test for null hypothesis of Pearson's coefficients of correlation equal to 0. 
Table B.2. Correlations among the main explanatory variables in the liquidity equation for U.S. and European listed commercial banks from 2000 to 2006

\begin{tabular}{|c|c|c|c|c|c|c|}
\hline & T12_RWA & T1_RWA & $\begin{array}{c}\mathrm{MKT}_{-} \\
\text {POW }\end{array}$ & GDP_GWT & $\mathrm{CB}$ & IBK1M_CB \\
\hline T12_RWA & 1 & & & & & \\
\hline T1_RWA & $\begin{array}{r}0.91 \\
0.00\end{array}$ & 1 & & & & \\
\hline MKT_POW & $\begin{array}{l}-0.13 \\
0.00\end{array}$ & $\begin{array}{l}-0.22 \\
0.00\end{array}$ & 1 & & & \\
\hline GDP_GWT & $\begin{array}{l}0.02 \\
0.14\end{array}$ & $\begin{array}{l}0.04 \\
0.01\end{array}$ & $\begin{array}{l}0.03 \\
0.12\end{array}$ & 1 & & \\
\hline $\mathrm{CB}$ & $\begin{array}{l}-0.06 \\
0.00\end{array}$ & $\begin{array}{l}-0.05 \\
0.00\end{array}$ & $\begin{array}{l}0.07 \\
0.00\end{array}$ & $\begin{array}{c}0.31 \\
0.00\end{array}$ & 1 & \\
\hline IBK1M_CB & $\begin{array}{l}-0.02 \\
0.21\end{array}$ & $\begin{array}{l}-0.04 \\
0.01\end{array}$ & $\begin{array}{l}0.16 \\
0.00\end{array}$ & $\begin{array}{c}0.12 \\
0.00\end{array}$ & $\begin{array}{r}0.13 \\
0.00\end{array}$ & 1 \\
\hline
\end{tabular}

All variables are expressed in percentage. $T 12 \_R W A$ : Tier 1 and 2 capital / total risk weighted assets; T1_RWA: Tier 1 capital / total risk weighted assets; $M K T_{-} P O W$ : total assets of bank $i$ in country $j$ / total assets of the banking system in country $j$; GDP_GWT: annual growth rate of real GDP; $C B$ : central bank policy rate; $I B K 1 M_{-} C B$ : spread of 1 month interbank rate and central bank policy rate. Figures in italics indicate -values of the T-statistics that test for null hypothesis of Pearson's coefficients of correlation equal to 0 . 
APPENDIX C

Table C.1. Including a proxy of market discipline in the capital equation with Tier 1 and 2 regulatory capital ratio for European and U.S. banks according to their size

\begin{tabular}{c}
\hline \multicolumn{2}{c}{ Tier 1 \& 2 regulatory capital ratio } \\
\cline { 2 - 3 } \\
\cline { 2 - 3 }
\end{tabular}

\begin{tabular}{|c|c|c|}
\hline \multirow{2}{*}{\multicolumn{3}{|c|}{$\begin{array}{c}\text { Tier } 1 \text { regulatory capital ratio } \\
\text { Small banks }\end{array}$}} \\
\hline & & \\
\hline${ }_{1 . a^{\prime}}$ & $1 . \mathbf{b}^{\prime}$ & 1. $\mathrm{c}^{\prime}$ \\
\hline
\end{tabular}

LC

\begin{tabular}{lccc} 
& & -0.02 & \\
I_NSFR & - & $(-0.78)$ & - \\
\hline Total Obs. & 669 & 669 & - \\
\hline \hline Panel B: US S. banks
\end{tabular}

Panel B: U.S. banks

LC $\quad \begin{gathered}-0.09 * * * \\ (-4.46)\end{gathered}$

I_NSFR

$-0.09 * * *$

-0.04
$(-0.37)$

\begin{tabular}{ccc} 
& 0.02 & - \\
\hline 189 & $(0.69)$ & - \\
\hline \hline-0.07 & 189 & - \\
$(-1.33)$ & - & - \\
- & -0.01 & -
\end{tabular}

CFR

$-0.06 * * *$

$-0.01$

\begin{tabular}{|c|c|c|c|c|c|c|}
\hline CFR & - & - & $\begin{array}{c}-0.05 * * * \\
(-4.17)\end{array}$ & - & - & $\begin{array}{l}0.06 * \\
(1.56)\end{array}$ \\
\hline Total Obs. & 1189 & 1189 & 1184 & 1597 & 1597 & 1597 \\
\hline
\end{tabular}

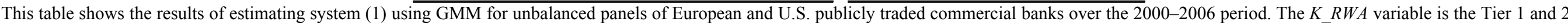

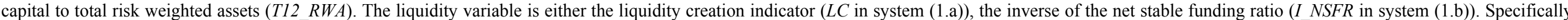

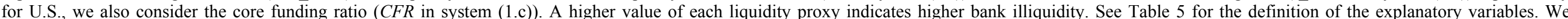

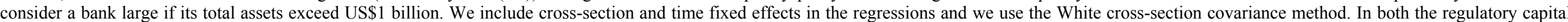

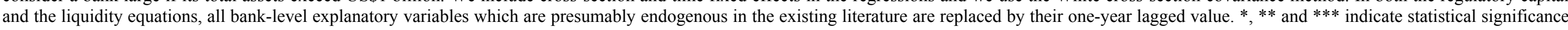
at the $10 \%, 5 \%$ and $1 \%$ levels, respectively.

Table C.2. Considering Tier 1 and 2 regulatory capital buffer for European banks according to their size

\begin{tabular}{|c|c|c|c|c|c|c|}
\hline & \multicolumn{3}{|c|}{ Tier $1 \& 2$ regulatory capital ratio } & \multicolumn{3}{|c|}{ Tier 1 regulatory capital ratio } \\
\hline & \multicolumn{3}{|c|}{ Large banks } & \multicolumn{3}{|c|}{ Small banks } \\
\hline & 1.a & $1 . \mathrm{b}$ & $1 . \mathrm{c}$ & 1. $\mathrm{a}^{\prime}$ & 1. $\mathrm{b}^{\prime}$ & $1 . \mathrm{c}$ \\
\hline \multicolumn{7}{|c|}{ Panel A: European banks } \\
\hline LC & $\begin{array}{c}0.01 \\
(0.26)\end{array}$ & - & - & $\begin{array}{c}-0.05 \\
(-0.49)\end{array}$ & - & - \\
\hline I_NSFR & - & $\begin{array}{c}-0.02 \\
(-1.03)\end{array}$ & - & - & $\begin{array}{c}-0.004 \\
(0.06)\end{array}$ & - \\
\hline Total Obs. & 669 & 669 & - & 189 & 189 & - \\
\hline
\end{tabular}

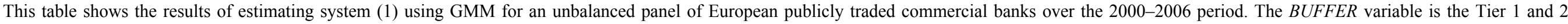

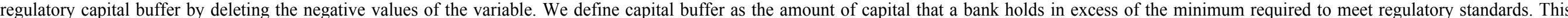

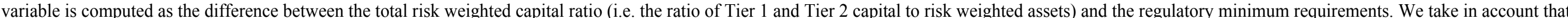

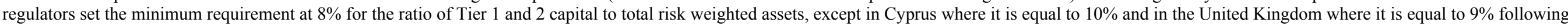

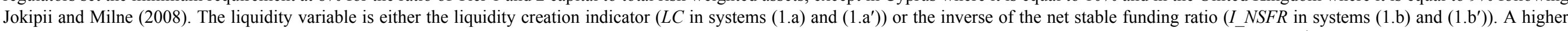

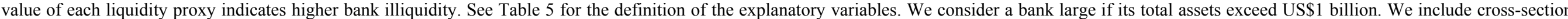

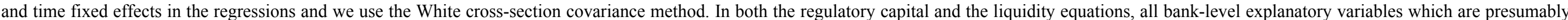
endogenous in the existing literature are replaced by their one-year lagged value. $* * *$ and $* * *$ indicate statistical significance at the $10 \%, 5 \%$ and $1 \%$ levels, respectively. 
Table C.3. The case of "true commercial banks" for European and U.S. banks according to their size

\begin{tabular}{|c|c|c|c|c|c|c|c|c|c|c|c|c|}
\hline & \multicolumn{6}{|c|}{ Tier 1 \& 2 regulatory capital ratio } & \multicolumn{6}{|c|}{ Tier 1 regulatory capital ratio } \\
\hline & & Large bank & & & nall ban & & & arge bank & & & aall bat & \\
\hline & 1.a & 1.b & 1.c & 1. a & 1.b & 1.c & 1. $\mathbf{a}^{\prime}$ & 1. $\mathbf{b}^{\prime}$ & 1. $\mathrm{c}^{\prime}$ & 1. $\mathbf{a}^{\prime}$ & 1. b' & 1.c' \\
\hline \multicolumn{13}{|c|}{ Panel A: European banks } \\
\hline LC & $\begin{array}{c}0.14 \\
(1.18)\end{array}$ & - & - & $\begin{array}{c}0.20 \\
(1.05)\end{array}$ & - & - & $\begin{array}{c}0.14 \\
(1.25)\end{array}$ & - & - & $\begin{array}{l}0.004 \\
(0.03)\end{array}$ & - & - \\
\hline I_NSFR & - & $\begin{array}{c}-0.03 \\
(-0.92)\end{array}$ & - & - & $\begin{array}{c}0.31 \\
(1.50)\end{array}$ & - & - & $\begin{array}{c}-0.03 \\
(-0.77)\end{array}$ & - & - & $\begin{array}{c}0.16 \\
(1.44)\end{array}$ & - \\
\hline Total Obs. & 588 & 588 & - & 151 & 151 & - & 588 & 588 & - & 151 & 151 & - \\
\hline \multicolumn{13}{|c|}{ Panel B: U.S. banks } \\
\hline LC & $\begin{array}{c}-0.10 * * * \\
(-5.11)\end{array}$ & - & - & $\begin{array}{c}-0.02 \\
(-0.41)\end{array}$ & - & - & $\begin{array}{c}-0.05 * * \\
(-2.30)\end{array}$ & - & - & $\begin{array}{c}-0.01 \\
(-0.25)\end{array}$ & - & - \\
\hline I_NSFR & - & $\begin{array}{c}-0.07 * * * \\
(-5.54)\end{array}$ & - & - & $\begin{array}{c}0.03 \\
(0.93)\end{array}$ & - & - & $\begin{array}{c}-0.03 * * \\
(-2.13)\end{array}$ & - & - & $\begin{array}{c}0.03 \\
(0.94)\end{array}$ & - \\
\hline CFR & - & - & $\begin{array}{c}-0.06 * * * * \\
(-5.07)\end{array}$ & - & - & $\begin{array}{c}0.08 * * \\
(2.28)\end{array}$ & - & - & $\begin{array}{c}-0.03 * * * * \\
(-2.53)\end{array}$ & - & - & $\begin{array}{r}0.08 * * \\
(2.17)\end{array}$ \\
\hline Total Obs. & 1131 & 1131 & 1126 & 1436 & 1436 & 1436 & 1131 & 1131 & 1126 & 1436 & 1436 & 1436 \\
\hline
\end{tabular}

This table shows the results of estimating system (1) using GMM for unbalanced panels of European and U.S. publicly traded commercial banks over the 2000-2006 period. The $K R W A$ variable is either the Tier 1 and 2 capital to total risk weighted assets $(T 12 R W A$ in systems $(1 . \mathrm{a}),(1 . \mathrm{b})$ and $(1 . \mathrm{c}))$ or the Tier 1 capital to total risk weighted assets $\left(T 1 R W A\right.$ in systems $\left(1 . \mathrm{a}^{\prime}\right),\left(1 . \mathrm{b}^{\prime}\right)$ and $\left.\left(1 . \mathrm{c}^{\prime}\right)\right)$. The liquidity variable is either

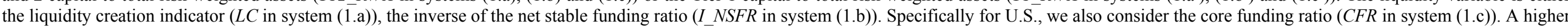

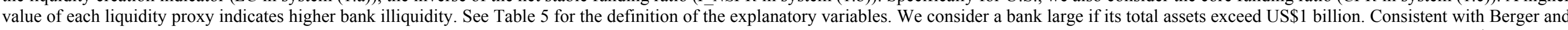

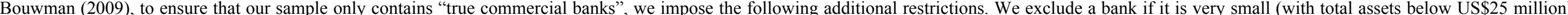

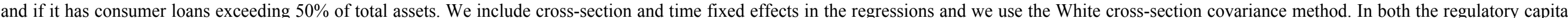

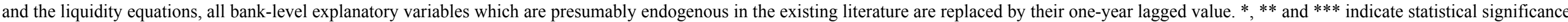
at the $10 \%, 5 \%$ and $1 \%$ levels, respectively.

\section{Table C.4. Introducing bank size in the liquidity equation for European and U.S. banks according to their size}

\begin{tabular}{|c|c|c|c|c|c|c|c|c|c|c|c|c|}
\hline & \multicolumn{6}{|c|}{ Tier 1 \& 2 regulatory capital ratio } & \multicolumn{6}{|c|}{$\begin{array}{l}\text { Tier } 1 \text { regulatory capital ratio } \\
\end{array}$} \\
\hline & \multicolumn{3}{|c|}{ Large banks } & \multicolumn{3}{|c|}{ Small banks } & \multicolumn{3}{|c|}{ Large banks } & \multicolumn{3}{|c|}{ Small banks } \\
\hline & 1.a & 1.b & $1 . \mathrm{c}$ & $1 . \mathbf{a}$ & 1.b & $1 . \mathrm{c}$ & 1. $\mathbf{a}^{\prime}$ & 1. $\mathrm{b}^{\prime}$ & 1. $\mathrm{c}^{\prime}$ & 1. $\mathbf{a}^{\prime}$ & 1. $\mathbf{b}^{\prime}$ & 1. $\mathrm{c}^{\prime}$ \\
\hline \multicolumn{13}{|c|}{ Panel A: European banks } \\
\hline LC & $\begin{array}{c}0.01 \\
(0.25)\end{array}$ & - & - & $\begin{array}{c}-0.02 \\
(-0.17)\end{array}$ & - & - & $\begin{array}{c}0.02 \\
(0.53)\end{array}$ & - & - & $\begin{array}{c}0.01 \\
(0.25)\end{array}$ & - & - \\
\hline I_NSFR & - & $\begin{array}{c}-0.01 \\
(-0.45)\end{array}$ & - & - & $\begin{array}{l}-0.003 \\
(-0.04)\end{array}$ & - & - & $\begin{array}{c}-0.01 \\
(-0.34)\end{array}$ & - & - & $\begin{array}{c}0.01 \\
(0.26)\end{array}$ & - \\
\hline Total Obs. & 669 & 669 & - & 189 & 189 & - & 669 & 669 & - & 189 & 189 & - \\
\hline \multicolumn{13}{|c|}{ Panel B: U.S. banks } \\
\hline LC & $\begin{array}{c}-0.10 * * * \\
(-5.07)\end{array}$ & - & - & $\begin{array}{l}-0.04 \\
(-0.85)\end{array}$ & - & - & $\begin{array}{c}-0.06 * * * \\
(-2.82)\end{array}$ & - & - & $\begin{array}{c}-0.04 \\
(-0.75)\end{array}$ & - & - \\
\hline I_NSFR & - & $\begin{array}{c}-0.07 * * * \\
(-5.43)\end{array}$ & - & - & $\begin{array}{l}0.003 \\
(0.09)\end{array}$ & - & - & $\begin{array}{c}-0.04 * * * \\
(-2.65)\end{array}$ & - & - & $\begin{array}{l}0.004 \\
(0.11)\end{array}$ & - \\
\hline CFR & - & - & $\begin{array}{c}-0.06 * * * \\
(-4.89)\end{array}$ & - & - & $\begin{array}{c}0.08 * * \\
(2.01)\end{array}$ & - & - & $\begin{array}{c}-0.03 * * * * \\
(-2.72)\end{array}$ & - & - & $\begin{array}{r}0.08 * * \\
(1.89)\end{array}$ \\
\hline Total Obs & 1189 & 1189 & 1184 & 1597 & 1597 & 1597 & 1189 & 1189 & 1184 & 1597 & 1597 & 1597 \\
\hline
\end{tabular}

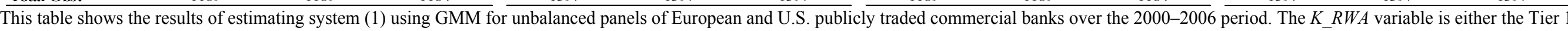

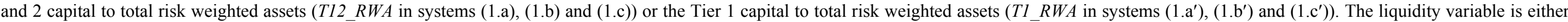

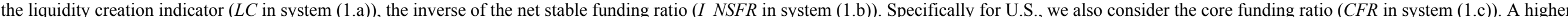

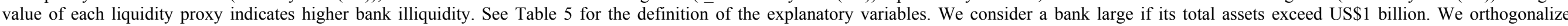

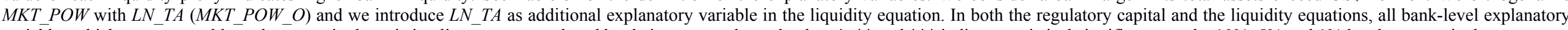

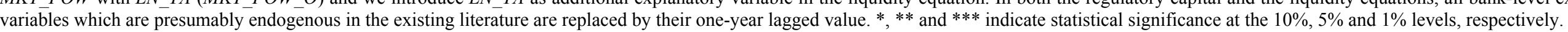


Table C.5. Orthogonalising $L N_{-} T A$ with $M K T_{-} P O W$ in the liquidity equation for European and U.S. banks according to their size

\begin{tabular}{|c|c|c|c|c|c|c|c|c|c|c|c|c|}
\hline & \multicolumn{6}{|c|}{ Tier 1 \& 2 regulatory capital ratio } & \multicolumn{6}{|c|}{ Tier 1 regulatory capital ratio } \\
\hline & \multicolumn{3}{|c|}{ Large banks } & \multicolumn{3}{|c|}{ Small banks } & \multicolumn{3}{|c|}{ Large banks } & \multicolumn{3}{|c|}{ Small banks } \\
\hline & 1.a & 1.b & $1 . \mathrm{c}$ & $1 . \mathbf{a}$ & 1.b & $1 . \mathrm{c}$ & 1. $\mathrm{a}^{\prime}$ & $1 . \mathrm{b}^{\prime}$ & 1. $\mathrm{c}^{\prime}$ & $1 . \mathrm{a}^{\prime}$ & $1 . \mathbf{b}^{\prime}$ & $1 . \mathrm{c}^{\prime}$ \\
\hline \multicolumn{13}{|c|}{ Panel A: European banks } \\
\hline LC & $\begin{array}{c}0.01 \\
(0.25)\end{array}$ & - & - & $\begin{array}{c}-0.02 \\
(-0.17)\end{array}$ & - & - & $\begin{array}{c}0.02 \\
(0.53)\end{array}$ & - & - & $\begin{array}{c}0.01 \\
(0.25)\end{array}$ & - & - \\
\hline I_NSFR & - & $\begin{array}{c}-0.01 \\
(-0.45)\end{array}$ & - & - & $\begin{array}{l}-0.003 \\
(-0.04)\end{array}$ & - & - & $\begin{array}{c}-0.01 \\
(-0.34)\end{array}$ & - & - & $\begin{array}{c}0.01 \\
(0.26)\end{array}$ & - \\
\hline Total Obs. & 669 & 669 & - & 189 & 189 & - & 669 & 669 & - & 189 & 189 & - \\
\hline \multicolumn{13}{|c|}{ Panel B: U.S. banks } \\
\hline LC & $\begin{array}{c}-0.10 * * * \\
(-5.07)\end{array}$ & - & - & $\begin{array}{c}-0.04 \\
(-0.85)\end{array}$ & - & - & $\begin{array}{c}-0.06 * * * \\
(-2.82)\end{array}$ & - & - & $\begin{array}{c}-0.04 \\
(-0.75)\end{array}$ & - & - \\
\hline I_NSFR & - & $\begin{array}{c}-0.07 * * * \\
(-5.43)\end{array}$ & - & - & $\begin{array}{l}0.003 \\
(0.09)\end{array}$ & - & - & $\begin{array}{c}-0.04 * * * \\
(-2.65)\end{array}$ & - & - & $\begin{array}{l}0.004 \\
(0.11)\end{array}$ & - \\
\hline CFR & - & - & $\begin{array}{c}-0.06 * * * \\
(-4.89)\end{array}$ & - & - & $\begin{array}{c}0.08 * * \\
(2.01)\end{array}$ & - & - & $\begin{array}{c}-0.03 * * * \\
(-2.72)\end{array}$ & - & - & $\begin{array}{c}0.08 * * \\
(1.89)\end{array}$ \\
\hline Total Obs. & 1189 & 1189 & 1184 & 1597 & 1597 & 1597 & 1189 & 1189 & 1184 & 1597 & 1597 & 1597 \\
\hline
\end{tabular}

Table C.6. Replacing $M K T_{-} P O W$ by $L N_{-} T A$ in the liquidity equation for European and U.S. banks according to their size

\begin{tabular}{|c|c|c|c|c|c|c|c|c|c|c|c|c|}
\hline & \multicolumn{6}{|c|}{ Tier $1 \& 2$ regulatory capital ratio } & \multicolumn{6}{|c|}{ Tier 1 regulatory capital ratio } \\
\hline & \multicolumn{3}{|c|}{ Large banks } & \multicolumn{3}{|c|}{ Small banks } & \multicolumn{3}{|c|}{ Large banks } & \multicolumn{3}{|c|}{ Small banks } \\
\hline & 1. a & 1.b & 1.c & 1. a & 1.b & 1.c & 1. a' & 1. $\mathbf{b}^{\prime}$ & 1. $\mathrm{c}^{\prime}$ & 1. a' & 1. $\mathbf{b}^{\prime}$ & 1. c' \\
\hline \multicolumn{13}{|c|}{ Panel A: European banks } \\
\hline LC & $\begin{array}{c}-0.01 \\
(-0.27)\end{array}$ & - & - & $\begin{array}{c}-0.77 * * \\
(-2.03)\end{array}$ & - & - & $\begin{array}{c}-0.01 \\
(-0.15)\end{array}$ & - & - & $\begin{array}{c}-0.35 \\
(-1.09)\end{array}$ & - & - \\
\hline I_NSFR & - & $\begin{array}{l}-0.001 \\
(-0.03)\end{array}$ & - & - & $\begin{array}{l}-0.16 \\
(-0.87)\end{array}$ & - & - & $\begin{array}{l}0.003 \\
(0.12)\end{array}$ & - & - & $\begin{array}{c}-0.05 \\
(-0.38)\end{array}$ & - \\
\hline Total Obs. & 669 & 669 & - & 189 & 189 & - & 669 & 669 & - & 189 & 189 & - \\
\hline \multicolumn{13}{|c|}{ Panel B: U.S. banks } \\
\hline LC & $\begin{array}{c}-0.10 * * * \\
(-5.08)\end{array}$ & - & - & $\begin{array}{c}-0.04 \\
(-0.89)\end{array}$ & - & - & $\begin{array}{c}-0.05 * * * \\
(-2.38)\end{array}$ & - & - & $\begin{array}{c}-0.04 \\
(-0.80)\end{array}$ & - & - \\
\hline I_NSFR & - & $\begin{array}{c}-0.07 * * * \\
(-5.45)\end{array}$ & - & - & $\begin{array}{l}0.004 \\
(0.10)\end{array}$ & - & - & $\begin{array}{c}-0.04 * * * \\
(-2.51)\end{array}$ & - & - & $\begin{array}{l}0.004 \\
(0.09)\end{array}$ & - \\
\hline CFR & - & - & $\begin{array}{c}-0.06 * * * * \\
(-4.80)\end{array}$ & - & - & $\begin{array}{c}0.09 * * \\
(2.19)\end{array}$ & - & - & $\begin{array}{c}-0.03 * * * * \\
(-2.43)\end{array}$ & - & - & $\begin{array}{c}0.08 * * \\
(1.92)\end{array}$ \\
\hline Total Obs. & 1189 & 1189 & 1184 & 1597 & 1597 & 1597 & 1189 & 1189 & 1184 & 1597 & 1597 & 1597 \\
\hline
\end{tabular}

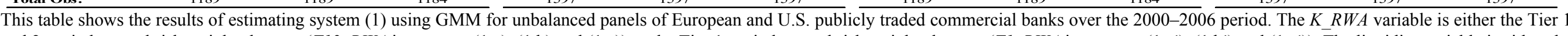

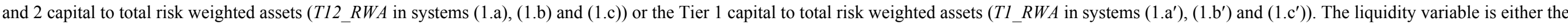

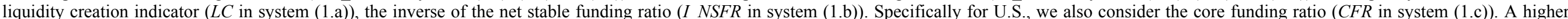

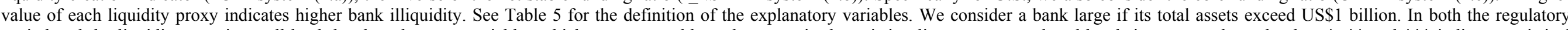

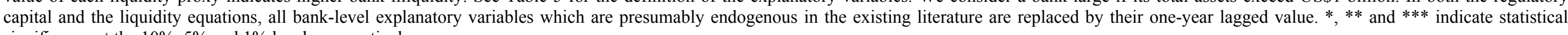
significance at the $10 \%, 5 \%$ and $1 \%$ levels, respectively. 
Table C.7. Using a measure of liquidity creation adjusted for equity for European and U.S. banks according to their size

\begin{tabular}{|c|c|c|c|c|}
\hline & \multicolumn{2}{|c|}{ Tier 1 \& 2 regulatory capital } & \multicolumn{2}{|c|}{ Tier 1 regulatory capital ratio } \\
\hline & Large banks & Small banks & Large banks & Small banks \\
\hline & 1. a & $1 . \mathbf{a}$ & $1 . a^{\prime}$ & $1 . a^{\prime}$ \\
\hline \multicolumn{5}{|c|}{ Panel A: European banks } \\
\hline LC_EE & $\begin{array}{l}0.002 \\
(0.04)\end{array}$ & $\begin{array}{c}-0.06 \\
(-0.76)\end{array}$ & $\begin{array}{l}-0.001 \\
(-0.03)\end{array}$ & $\begin{array}{c}-0.01 \\
(-0.09)\end{array}$ \\
\hline Total Obs. & 669 & 189 & 669 & 189 \\
\hline \multicolumn{5}{|c|}{ Panel B: U.S. banks } \\
\hline LC_EE & $\begin{array}{c}-0.08 * * * \\
(-5.06)\end{array}$ & $\begin{array}{c}0.01 \\
(0.14)\end{array}$ & $\begin{array}{c}-0.05 * * * \\
(-2.75)\end{array}$ & $\begin{array}{c}0.01 \\
(0.23)\end{array}$ \\
\hline Total Obs. & 1189 & 1597 & 1189 & 1597 \\
\hline
\end{tabular}

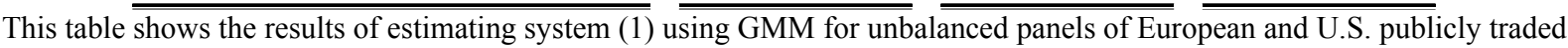
commercial banks over the 2000-2006 period. The $K R W A$ variable is either the Tier 1 and 2 capital to total risk weighted assets $\left(T 12_{-} R W A\right)$ or the Tier 1 capital to total risk weighted assets $\left(T 1 \_R W\right)$. The liquidity variable is an indicator of liquidity creation calculated by excluding equity $(L C E E)$. A higher value of this liquidity proxy indicates higher bank illiquidity. See Table 5 for the definition of the explanatory variables. We consider a bank large if its total assets exceed US $\$ 1$ billion. We include cross-section and time fixed effects in the regressions and we use the White cross-section covariance method. In both the regulatory capital and the liquidity equations, all bank-level explanatory variables which are presumably endogenous in the existing literature are replaced by their one-year lagged value. $*, * *$ and $* * *$ indicate statistical significance at the $10 \%, 5 \%$ and $1 \%$ levels, respectively. 
Table C.8. Using alternative weights for stable deposits in the inverse of the net stable funding ratio for European and U.S. banks according to their size

\begin{tabular}{|c|c|c|c|c|c|c|c|c|c|c|c|c|}
\hline & \multicolumn{6}{|c|}{ Tier $1 \& 2$ regulatory capital ratio } & \multicolumn{6}{|c|}{ Tier 1 regulatory capital ratio } \\
\hline & \multicolumn{3}{|c|}{ Large banks } & \multicolumn{3}{|c|}{ Small banks } & \multicolumn{3}{|c|}{ Large banks } & \multicolumn{3}{|c|}{ Small banks } \\
\hline & 1. a & 1. b & 1.c & 1.a & 1.b & 1.c & 1. $\mathrm{a}^{\prime}$ & 1. $\mathrm{b}^{\prime}$ & 1. $c^{\prime}$ & 1. $\mathrm{a}^{\prime}$ & $1 . \mathrm{b}^{\prime}$ & 1. $c^{\prime}$ \\
\hline \multicolumn{13}{|c|}{ Panel A: European banks } \\
\hline I_NSFR_D05 & $\begin{array}{c}-0.02 \\
(-1.01)\end{array}$ & - & - & $\begin{array}{l}-0.002 \\
(-0.09)\end{array}$ & - & - & $\begin{array}{c}-0.02 \\
(-1.05)\end{array}$ & - & - & $\begin{array}{c}0.01 \\
(0.31)\end{array}$ & - & - \\
\hline I_NSFR_D085 & - & $\begin{array}{c}-0.03 \\
(-1.02)\end{array}$ & - & - & $\begin{array}{l}0.004 \\
(0.09)\end{array}$ & - & - & $\begin{array}{c}-0.03 \\
(-1.06)\end{array}$ & - & - & $\begin{array}{c}0.02 \\
(0.45)\end{array}$ & - \\
\hline I_NSFR_D1 & - & - & $\begin{array}{l}-0.03 \\
(-1.00)\end{array}$ & - & - & $\begin{array}{c}0.01 \\
(0.13)\end{array}$ & - & - & $\begin{array}{l}-0.03 \\
(-1.03)\end{array}$ & - & - & $\begin{array}{c}0.02 \\
(0.48)\end{array}$ \\
\hline Total Obs. & 669 & 669 & - & 189 & 189 & - & 669 & 669 & - & 189 & 189 & - \\
\hline \multicolumn{13}{|c|}{ Panel B: U.S. banks } \\
\hline I_NSFR_D05 & $\begin{array}{c}-0.08 * * * \\
(-5.47)\end{array}$ & - & - & $\begin{array}{c}-0.01 \\
(-0.20)\end{array}$ & - & - & $\begin{array}{c}-0.04 * * * \\
(-2.76)\end{array}$ & - & - & $\begin{array}{l}-0.002 \\
(-0.05)\end{array}$ & - & - \\
\hline I_NSFR_D085 & - & $\begin{array}{c}-0.07 * * * \\
(-5.49)\end{array}$ & - & - & $\begin{array}{c}0.01 \\
(0.27)\end{array}$ & - & - & $\begin{array}{c}-0.04 * * * \\
(-2.62)\end{array}$ & - & - & $\begin{array}{c}0.01 \\
(0.23)\end{array}$ & - \\
\hline I_NSFR_D1 & - & - & $\begin{array}{c}-0.07 * * * \\
(-5.47)\end{array}$ & - & - & $\begin{array}{c}0.01 \\
(0.38)\end{array}$ & - & - & $\begin{array}{c}-0.04 * * * \\
(-2.58)\end{array}$ & - & - & $\begin{array}{c}0.01 \\
(0.29)\end{array}$ \\
\hline Total Obs. & 1189 & 1189 & 1184 & 1597 & 1597 & 1597 & 1189 & 1189 & 1184 & 1597 & 1597 & 1597 \\
\hline
\end{tabular}

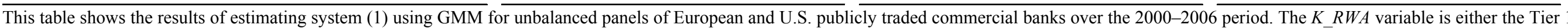

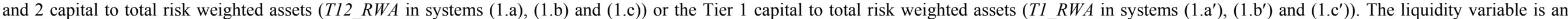

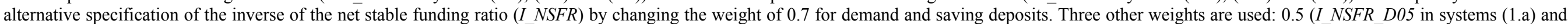

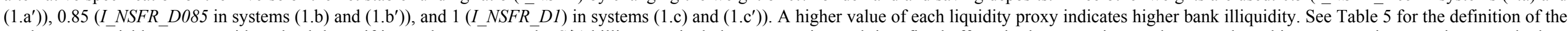

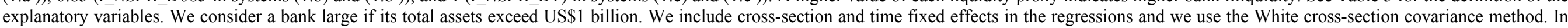

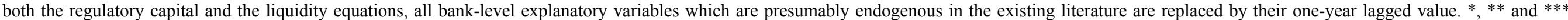
indicate statistical significance at the $10 \%, 5 \%$ and $1 \%$ levels, respectively. 
Table C.9. Using alternative liquidity proxies for European and U.S. banks according to their size

\begin{tabular}{|c|c|c|c|c|c|c|c|c|c|c|c|c|}
\hline & \multicolumn{6}{|c|}{ Tier $1 \& 2$ regulatory capital ratio } & \multicolumn{6}{|c|}{ Tier 1 regulatory capital ratio } \\
\hline & \multicolumn{3}{|c|}{ Large banks } & \multicolumn{3}{|c|}{ S Small banks } & \multicolumn{3}{|c|}{ Large banks } & \multicolumn{3}{|c|}{ "Small banks } \\
\hline & 1.a & $1 . \mathrm{b}$ & $1 . \mathrm{c}$ & 1.a & $1 . \mathrm{b}$ & $1 . \mathrm{c}$ & $1 . \mathrm{a}^{\prime}$ & $1 . \mathrm{b}^{\prime}$ & $1 . \mathrm{c}^{\prime}$ & $1 . \mathrm{a}^{\prime}$ & $1 . \mathrm{b}^{\prime}$ & $1 . \mathrm{c}^{\prime}$ \\
\hline \multicolumn{13}{|c|}{ Panel A: European banks } \\
\hline IA_IL & $\begin{array}{l}-0.004 \\
(-0.55)\end{array}$ & - & - & $\begin{array}{c}-0.01 \\
(-0.83)\end{array}$ & - & - & $\begin{array}{l}-0.002 \\
(-0.37)\end{array}$ & - & - & $\begin{array}{l}-0.004 \\
(-0.55)\end{array}$ & - & - \\
\hline LTR & - & $\begin{array}{l}-0.005 \\
(-0.59)\end{array}$ & - & - & $\begin{array}{l}-0.001 \\
(-0.10)\end{array}$ & - & - & $\begin{array}{l}-0.004 \\
(-0.46)\end{array}$ & - & - & $\begin{array}{l}0.001 \\
(0.26)\end{array}$ & - \\
\hline Total Obs. & 669 & 669 & - & 189 & 189 & - & 669 & 669 & - & 189 & 189 & - \\
\hline \multicolumn{13}{|c|}{ Panel B: U.S. banks } \\
\hline IA_IL & $\begin{array}{c}-0.10 * * * \\
(-2.90)\end{array}$ & - & - & $\begin{array}{c}-0.10 * * * \\
(-6.04)\end{array}$ & - & - & $\begin{array}{c}-0.06 * * * \\
(-2.42)\end{array}$ & - & - & $\begin{array}{c}-0.09 * * * \\
(-4.94)\end{array}$ & - & - \\
\hline LTR & - & $\begin{array}{c}0.14 * * \\
(2.07)\end{array}$ & - & - & $\begin{array}{c}-0.02 \\
(-0.79)\end{array}$ & - & - & $\begin{array}{c}0.08 \\
(1.59)\end{array}$ & - & - & $\begin{array}{l}-0.01 \\
(-0.44)\end{array}$ & - \\
\hline CDR & - & - & $\begin{array}{c}-0.01 * * * \\
(-4.76) \\
\end{array}$ & - & - & $\begin{array}{c}0.05 * * * \\
(3.11) \\
\end{array}$ & - & - & $\begin{array}{c}-0.01 * * * \\
(-3.04) \\
\end{array}$ & - & - & $\begin{array}{c}0.04 * * * \\
(2.63) \\
\end{array}$ \\
\hline Total Obs. & 1189 & 1189 & 1184 & 1597 & 1597 & 1597 & 1189 & 1189 & 1184 & 1597 & 1597 & 1597 \\
\hline
\end{tabular}

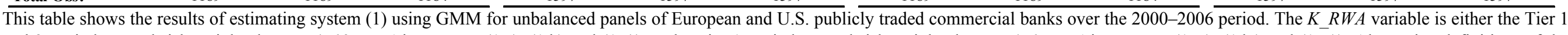

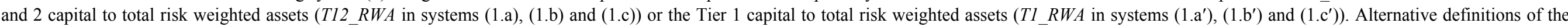

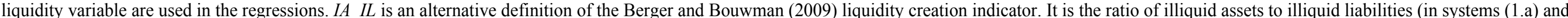

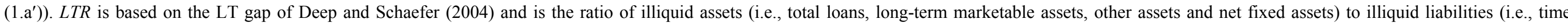

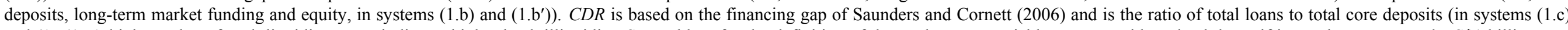

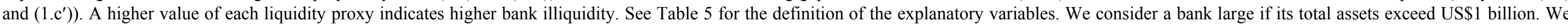

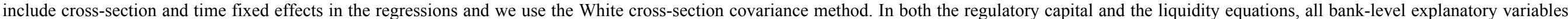
which are presumably endogenous in the existing literature are replaced by their one-year lagged value. *,** and *** indicate statistical significance at the $10 \%, 5 \%$ and $1 \%$ levels, respectively. 
Table C.10. The case of small U.S. "community banks"

\begin{tabular}{|c|c|c|c|c|c|c|}
\hline & \multicolumn{3}{|c|}{ Tier $1 \& 2$ regulatory capital ratio } & \multicolumn{3}{|c|}{ Tier 1 regulatory capital ratio } \\
\hline & 1.a & $1 . \mathrm{b}$ & 1. c & 1. $\mathrm{a}^{\prime}$ & $1 . b^{\prime}$ & 1. $c^{\prime}$ \\
\hline LC & $\begin{array}{c}-0.01 \\
(-0.13)\end{array}$ & - & - & $\begin{array}{c}-0.02 \\
(-0.43)\end{array}$ & - & - \\
\hline I_NSFR & - & $\begin{array}{c}0.05 \\
(1.52)\end{array}$ & - & - & $\begin{array}{c}0.04 \\
(1.05)\end{array}$ & - \\
\hline CFR & - & - & $\begin{array}{c}0.17 * * * \\
(3.41)\end{array}$ & - & - & $\begin{array}{c}0.15 * * * \\
(2.89)\end{array}$ \\
\hline Total Obs. & 1380 & 1380 & 1380 & 1380 & 1380 & 1380 \\
\hline
\end{tabular}

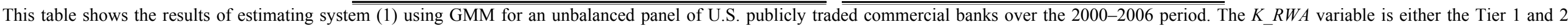

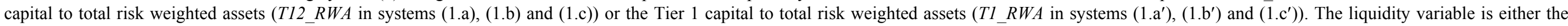

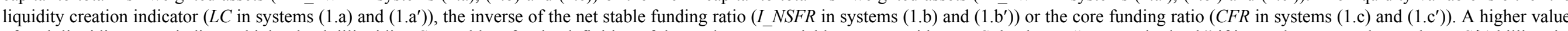

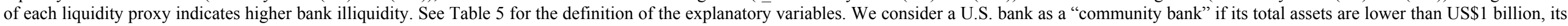

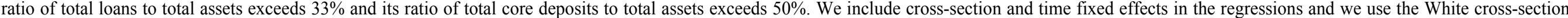

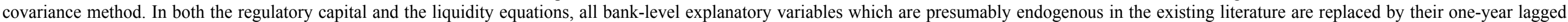
value. $* * *$ and $* * *$ indicate statistical significance at the $10 \%, 5 \%$ and $1 \%$ levels, respectively.

\section{Table C.11. The case of "very small" U.S. banks}

\begin{tabular}{|c|c|c|c|c|c|c|}
\hline & \multicolumn{3}{|c|}{ Tier $1 \& 2$ regulatory capital ratio } & \multicolumn{3}{|c|}{ Tier 1 regulatory capital ratio } \\
\hline & 1.a & 1.b & 1.c & 1. $\mathrm{a}^{\prime}$ & $1 . \mathbf{b}^{\prime}$ & 1. $c^{\prime}$ \\
\hline $\mathrm{LC}$ & $\begin{array}{c}0.08 \\
(1.53)\end{array}$ & - & - & $\begin{array}{c}0.06 \\
(1.04)\end{array}$ & - & - \\
\hline I_NSFR & - & $\begin{array}{c}0.12 * * * \\
(3.59)\end{array}$ & - & - & $\begin{array}{l}0.08 * \\
(1.67)\end{array}$ & - \\
\hline CFR & - & - & $\begin{array}{c}0.10 * * * \\
(3.49)\end{array}$ & - & - & $\begin{array}{c}0.07 * * \\
(2.04)\end{array}$ \\
\hline Total Obs. & 884 & 884 & 884 & 884 & 884 & 884 \\
\hline
\end{tabular}

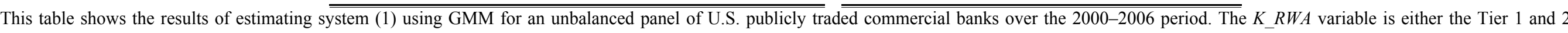

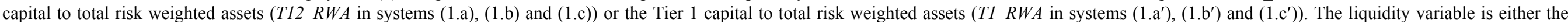

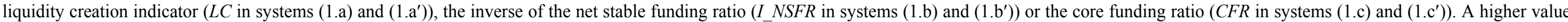

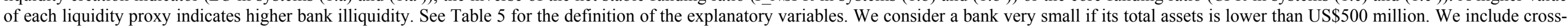

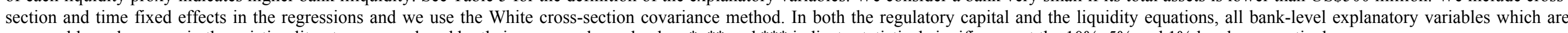
presumably endogenous in the existing literature are replaced by their one-year lagged value. $*, * *$ and $* * *$ indicate statistical significance at the $10 \%, 5 \%$ and $1 \%$ levels, respectively. 
Table C.12. The case of small U.S. banks with a restricted access to financial markets

\begin{tabular}{|c|c|c|c|c|c|c|}
\hline & \multicolumn{3}{|c|}{ Tier $1 \& 2$ regulatory capital ratio } & \multicolumn{3}{|c|}{ Tier 1 regulatory capital ratio } \\
\hline & $1 . \mathbf{a}$ & $\overline{c 1 . b}$ & $\overline{1 . \mathrm{c}}$ & 1. $\mathbf{a}^{\prime}$ & 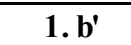 & 1. $c^{\prime}$ \\
\hline LC & $\begin{array}{c}-0.30 * * * \\
(-3.83)\end{array}$ & - & - & $\begin{array}{c}-0.55 * * * \\
(-4.88)\end{array}$ & - & - \\
\hline I_NSFR & - & $\begin{array}{c}0.46 * * * \\
(4.23)\end{array}$ & - & - & $\begin{array}{c}0.44 * * * \\
(4.77)\end{array}$ & - \\
\hline CFR & - & - & $\begin{array}{c}0.14 * * * \\
(2.85)\end{array}$ & - & - & $\begin{array}{c}0.18 * * * \\
(3.89)\end{array}$ \\
\hline Total Obs. & 788 & 788 & 788 & 788 & 788 & 788 \\
\hline
\end{tabular}

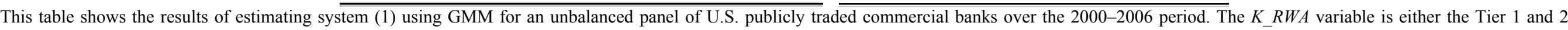

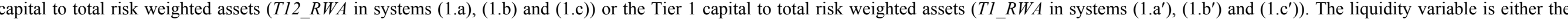

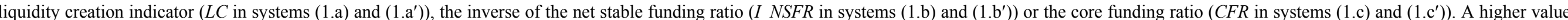

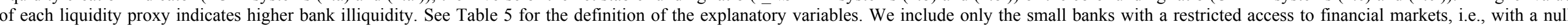

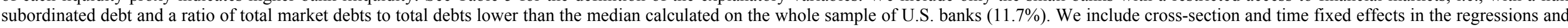

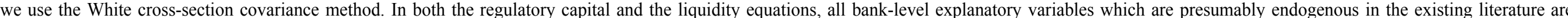
replaced by their one-year lagged value. ${ }^{*}, * *$ and $* * *$ indicate statistical significance at the $10 \%, 5 \%$ and $1 \%$ levels, respectively. 